\title{
THE IMPACT OF FISCAL INCENTIVES ON STUDENT DISABILITY RATES
}

\author{
Julie Berry Cullen
}

Working Paper 7173

http://www.nber.org/papers/w7173

\author{
NATIONAL BUREAU OF ECONOMIC RESEARCH \\ 1050 Massachusetts Avenue \\ Cambridge, MA 02138 \\ June 1999
}

I would like to thank Mathew Eichner, David Figlio, Jonathan Gruber, Lawrence Kenny, Susanna Loeb, Steven Levitt, Eric Hanushek, David Neumark, James Poterba, Steven Rivkin, Joel Slemrod, Gary Solon, Rohini Somanathan and participants in the McMaster University, Michigan State University, University of Florida, University of Michigan, University of Rochester, University of Western Ontario, and York University seminar series for helpful comments and discussions. I am grateful to the Alfred P. Sloan Foundation for financial support. All remaining errors are my own. All opinions expressed are those of the authors and not those of the National Bureau of Economic Research.

(C) 1999 by Julie Berry Cullen. All rights reserved. Short sections of text, not to exceed two paragraphs, may be quoted without explicit permission provided that full credit, including $\mathcal{C}$ notice, is given to the source. 
The Impact of Fiscal Incentives on

Student Disability Rates

Julie Berry Cullen

NBER Working Paper No. 7173

June 1999

JEL No. $\mathrm{H} 7$

\begin{abstract}
Student disability rates have grown by over 50 percent over the past two decades and are continuing to rise. Policy discussion has linked this trend to state funding formulas that reward local school districts for identifying additional students with special needs. However, there is little empirical evidence on the role of these fiscal parameters in explaining student disability rates, or, more generally, on the responsiveness of local program take-up rates to intergovernmental fiscal incentives. In order to estimate the elasticity of student disability rates with respect to the generosity of state reimbursements, I use variation in the state aid generated by serving a disabled student across local school districts in Texas from 1991-92 through 1996-97. The take-up response is identified from sharp changes in the relative treatment of districts of differing wealth that arise from court-mandated changes in the structure of school finance equalization. My central estimates imply that fiscal incentives can explain over 35 percent of the recent growth in student disability rates in Texas. The magnitude of the institutional response varies by district size and enrollment concentration, student race/ethnicity composition, and the level of fiscal constraint.
\end{abstract}

Julie Berry Cullen University of Michigan

Department of Economics

Ann Arbor, MI 48109-1220

and NBER

jbcullen@umich.edu 
There is a substantial literature documenting the relationship between social insurance program generosity and caseloads. ${ }^{1}$ The nature of this relationship is important to program design because changes in the size and characteristics of beneficiary populations not only affect the ultimate costs but may also undermine stated policy objectives. Most analyses of the impact of financial incentives on take-up focus on individuals' decisions to participate, and little is known about how bureaucracies respond to similar incentives to expand caseloads. This paper explores how institutional take-up responds to program generosity by quantifying the relationship between official student disability rates and the level of state special education aid to school districts.

Programs that target resources according to disability status are becoming increasingly important in the United States. The number of adult Disability Insurance (DI) and Supplemental Security Income (SSI) recipients has increased from 6 million to nearly 10 million over the past two decades, driving the increase in the share of cash welfare expenditures dedicated to these programs. Childhood disability rolls and outlays have exhibited parallel growth following recent reforms to SSI (GAO 1994). Growing fiscal claims are also made on behalf of disabled children through school-based disability programs as special education enrollments continue to rise. Since 1977, the fraction of elementary and secondary students classified as disabled has increased from 8 to over 12 percent. Over the same period, the fraction of school district spending that is dedicated to special education services has increased from 4 to 17 percent (Rothstein and Miles 1995). In 1993-94, 5.4 million students participated in special education at an estimated cost of over 32 billion dollars (Parrish 1996).

There are several explanations for the rise in adult and childhood disability rates. First, the pool of eligible individuals has been expanding because of changes in cultural norms regarding what constitutes disability. According to this view, programs that were primarily intended for the severely physically disabled have been extended to include mental and emotional disabilities. Take-up of disability benefits among eligibles has increased with diminished stigma and the establishment of a legal support system. At the same time, sociodemographic factors that determine the at-risk population, such as the childhood poverty rate, have been worsening (Bassi 1988). Finally, the financial incentives embedded in the disability

\footnotetext{
${ }^{1}$ See, for example, Moffitt (1992), Krueger (1990), Anderson and Meyer (1997), Bound and Waidmann (1992), and Lumsdaine and Wise (1994) for reviews and analyses of this issue for various social insurance programs.
} 
programs may influence disability rates. Empirical analyses relating individual take-up of DI and SSI to benefit generosity (e.g. Kubik 1997, Bound and Waidmann 1992, Parsons 1980) find evidence consistent with an important role for financial incentives in explaining the time trends in self-reported disability. The extent to which state school finance program parameters determine official student disability rates and likely program effectiveness will depend on how school districts respond to similar incentives to expand student disability caseloads.

Fiscal incentives to classify marginal students as disabled arise because the claim that a locality can make on state elementary and secondary education funds typically increases with the number of students classified. The goal of the original 1975 special education legislation, the Education for All Handicapped Children Act (EHA), ${ }^{2}$ was to guarantee disabled students access to an appropriate public education. At the time, Congressional investigations revealed that twothirds of children with disabilities were either totally excluded from or ignored within public schools (Verstegen 1994). Following the passage of the federal mandate, states designed school finance policies to encourage school districts to locate and provide additional assistance to students with severe disabilities. Since then, special education has evolved into a program that primarily serves students with mild learning disabilities. Critics claim that vague definitions of disabling conditions coupled with financial incentives have pushed student disability rates to the current levels at which over one in eight students is classified as disabled. Due to this popular perception, a nationwide reform effort is currently under way to reduce the incentives in state school finance policies for localities to inflate student disability rates.

In order to estimate the elasticity of official student disability rates with respect to fiscal incentives, I rely on variation in the gain in state revenue from labeling an additional student as disabled across school districts in Texas over the academic years 1991-92 to 1996-97. In Texas, because of the structure of the school finance equalization policy, this revenue increase depends on a district's tax base wealth. Court-mandated changes in the overall equalization formula dramatically increased the relative revenue gain for higher wealth districts in the middle of the period. While disability rates had been growing more slowly in high wealth districts, growth in these districts outpaced lower wealth districts following the policy change.

In a reduced-form specification that controls for district-specific trends, I relate student disability rates to these policy-induced movements in the incentive to classify students as

\footnotetext{
${ }^{2}$ Individuals with Disabilities Education Act (IDEA) is the current version of this legislation.
} 
disabled. The results indicate that local responses to state incentives play an important role in determining the ultimate size of special education programs and, therefore, in determining the allocation of resources within and across schools. I find that a 10 percent increase in the supplemental revenue generated by a disabled student leads to a 1.4 percent increase in the fraction of students classified as disabled. The strong positive elasticity is robust to a variety of specification tests. The magnitude implies that over 35 percent of the six-year increase in student disability rates in Texas can be explained by the contemporaneous increase in fiscal incentives. As expected, the estimated elasticity is larger for the mildest and less well-defined disability categories, such as learning disability and speech impairment. The elasticity is also larger for smaller districts and for districts in which student enrollment is more concentrated across schools. While the welfare effects of the take-up response are ambiguous, the fact that non-majority students and students in fiscally constrained districts are more likely to be classified in response to fiscal incentives suggests that school districts may be classifying students for fiscal gain.

The remainder of the paper is divided into four sections. Section 1 provides background on program take-up in the context of special education and relates this paper's approach to existing literature. Section 2 describes the empirical strategy and explains the source of identifying variation in fiscal incentives. Section 3 presents baseline estimates of the elasticity of student disability rates with respect to fiscal incentives and the results from a variety of sensitivity tests and extensions. Section 4 concludes.

\section{Background}

Special education encompasses a wide variety of disabilities and interventions. There are state and federal guidelines delineating which physical, emotional, and mental disabilities are eligible for special services provided in the school. Eligible students may be severely physically or mentally handicapped, or may be very difficult to distinguish from non-disabled slow-learning students. For reference, the Texas guidelines for eligible disabling conditions are summarized in the Appendix. As Figure 1 demonstrates for Texas, the large majority of students currently served in special education nationally have mild disabilities; learning disabled, speech impaired, and emotionally disturbed students comprise 80 percent of the special needs population served (U.S. Department of Education 1998). 
The types of services that special needs students receive may include additional support in the regular classroom, pull-out for part of the day in a resource room, or instruction in separate classes and schools. Students with relatively mild disabilities tend to be served in less restrictive and less expensive instructional settings (See Figure 2). The excess costs associated with educating disabled students vary according to the intensity of instruction provided. ${ }^{3}$ In an analysis based on nationally representative data from 1987-88, Moore et al (1988) find that per pupil spending on special education students is on average 2.3 times per pupil spending on regular education students. Using Massachusetts expenditure data, Chambers (1998) finds a very similar average cost ratio, and disability and setting-specific ratios that range from 1.24 for learning disabled students served within regular elementary schools to 31.4 for students with multiple disabilities served in external facilities.

States have implemented a variety of funding mechanisms to deliver resources to districts in a manner that accounts for these heterogeneous costs. ${ }^{4}$ The dominant mechanism prior to the recent wave of state special education finance reforms involves pupil weighting, in which special education students are weighted more heavily than general education students within the basic school finance formula. The weights are often specific to the type of disability, the type of instructional setting, and/or the grade-level. Pupil-weighting has the advantage of providing a relatively close link between districts' resource needs and the flow of state funds. However, because the financial rewards are directly tied to labeling and tend to be only loosely tied to additional costs incurred, school officials may have an incentive to over-classify or misclassify students as special needs while providing the minimum acceptable level of special services. This incentive is enhanced by state policies that put few restrictions on how funds generated by disabled students are spent. ${ }^{5}$ To eliminate potential distortions, several states have recently

\footnotetext{
${ }^{3}$ In 1993, the national average pupil-teacher ratio was 24 to one for learning disabled and speech impaired students, and as low as six to one for the more severely disabled (U.S. Department of Education 1996)

${ }^{4}$ See Parrish et al (1997) for a detailed analysis of the various state special education funding mechanisms. The federal government has traditionally provided a flat grant to states based on the total number of disabled students served in special education in each state. Since the IDEA Amendment of 1997, a new formula based on total student enrollment ( 85 percent) and school-age poverty rates ( 15 percent) is being phased in. The federal government's share of special education expenditures has never exceeded 10 percent.

${ }_{5}^{5}$ For example, in Massachusetts, revenue generated by disabled students can be allocated to any item within the local budget. In 35 percent of states, districts are not required to expend funds generated by special education students on special education (Chambers 1996). In Texas, the state requires that 85 percent of special education revenues be dedicated to educating disabled students. However, until recently, the method of accounting did not adequately distinguish regular and special education expenditures.
} 
implemented prospective reimbursement systems in which special education aid is based only on total district enrollment.

The importance of fiscal incentives in determining the rate at which students are classified as disabled clearly depends on how much discretion local officials maintain in implementing special education programs. Federal and state mandates attempt to limit local discretion by explicitly prescribing the procedure for identifying and serving disabled students. The process begins with the referral of a student by either an appropriate school employee (e.g. a teacher, counselor, or psychologist) or a parent. Experts (e.g. psychologists, physicians, and educational diagnosticians) then administer a battery of tests to determine whether the student has a recognized disability. If the student is deemed disabled, school specialists must develop an individualized education plan (IEP) that describes the services that will be provided to address the student's needs. For the child to be served in special education, the child's parents have to approve both the disability classification and the IEP.

Despite the strict procedural regulations, there is evidence of substantial local leeway in practice. First, though assessment tests are designed to provide rich information about students' abilities and deficiencies, the primary determinant of placement in special education is the initial referral (Thurlow and Ysseldyke 1980). Mellard (1983) summarizes existing research on assessment as finding that special education placements are "not consistently made on the basis of the data, and are frequently recommended in spite of the data." In field work, Mellard (1985) also finds that the data are not necessarily objective. He discovers patterns of selective subtest administration that suggest examiners may "shop" for tests to confirm their hypotheses. Finally, the clinician is supposed to consider student behaviors other than performance on test indicators, yet these other criteria are typically not well-defined or operationalized. Because of the scope for subjectivity in assessment, it is not surprising that the functional abilities of students classified as disabled and the services provided vary dramatically across school districts (Singer et al 1989).

Given that localities can largely control special education program size, school districts would be expected to maximize the state payment per student by classifying the entire student body as disabled - if labeling students as disabled were costless. However, in reality, the incentive to leverage state and federal funds will be tempered by both fiscal and non-fiscal costs. The financial costs begin with assessment costs, which can be large relative to average special 
education instructional costs. ${ }^{6}$ Additional instructional costs also likely accompany a student's assignment to special education, though marginal costs may be minimal for slow-learning students who would otherwise be served in remedial education. Non-financial costs to aggressively classifying students as disabled include the possibility of attracting a state audit or censure. Also, parents may object to having their child labeled as disabled if special education does not involve more intensive resources, or even if it does because of the potential stigma associated with the label. Only those districts that face revenue incentives that outweigh the costs will engage in relabeling. The mechanism through which higher fiscal incentives are translated into higher disability rates in school districts will depend on the political process through which such decisions are made, and particularly on how the costs and benefits are distributed.

If classifying marginal students as disabled were to generate pre-determined excess costs, then the impact of special education finance policies on special education program size could be modeled in the same way as traditional categorical or matching grants. That is, these policies would alter the relative cost of expanding special education programs in a way that could be readily mapped into shifts in the budget constraint of the relevant local decision-maker. Empirical applications within the literature on intergovernmental grants commonly adopt a median voter model and consider decisions about the level of spending on a single public good. Analyses of local school spending demonstrate that localities are quite responsive to fiscal incentives within state education grants (Reschovsky and Schwartz 1992).

The disability classification behavior of school districts does not fit directly into this framework. Official disability rates at the school district level will be influenced by a combination of practitioner, voter, and bureaucratic preferences, as well as state and federal regulations. Not only is the decision mechanism likely to be more complicated, the additional costs associated with classifying a student as disabled are not deterministic. State school finance formulas do not in general provide resources based on excess special education expenditures, but instead reward labeling by providing a given amount of revenue for each disabled student. Because the net financial gain from labeling an additional student will vary district to district and child to child, modeling explicit budgetary tradeoffs is not possible without more detailed information on the associated special education costs than is available. Therefore, I model the

\footnotetext{
${ }^{6}$ Moore et al (1988) estimate that 13 percent of total special education expenditures are dedicated to assessment.
} 
official rate of student disability as a function the gross gain in state revenues. This gross gain can be thought of as the marginal financial benefit to expanding the student disability rate, which is then implicitly traded off against the unmeasured marginal costs. Rather than developing a specific model of the decision-making process, I investigate a reduced-form specification, assuming that increases in the gross revenue gain would be expected to increase disability rates regardless of the political process.

There is limited evidence on bureaucratic responses to incentives to manipulate caseloads from other contexts. Recent studies evaluate the impact of performance standards on the implementation of job-training programs. ${ }^{7}$ Tying administrators' pay to the performance of program participants not only provides incentives for more effective program management, but also provides incentives for program administrators to selectively admit those candidates that are most likely to succeed. Though the evidence does not support this contention for job training programs, this type of moral hazard appears important in a more closely related area. Following the reform to Medicare reimbursements in 1983, diagnoses of the elderly crept into those categories with relatively higher reimbursement rates (Carter et al 1990).

There are also case studies that provide qualitative evidence that fiscal incentives affect caseloads in the context of special education. Montgomery (1995) discusses the impact of recent special education finance reform in Oregon. The system was changed from a system that reimbursed excess special education costs to one in which districts receive two times as much state aid per disabled student as per regular education student, up to a cap of 11 percent of enrollment. Montgomery describes interviews with special education directors who claim to have been asked by their superintendents to bring the disabled count up to 11 percent. She also reports:

"One director admitted to changing district policy on identification of children for special education in kindergarten. Previously this district had tended not to identify children in kindergarten. Now, to increase their count, they were starting to identify these children, although they were not very comfortable pushing [teachers] to label."8

In a separate study, Kane and Johnson (1993) document the outcome of Vermont's movement from a system that provided additional funds per student classified as disabled to a system that

\footnotetext{
${ }^{7}$ See, for example, Courty and Marschke (1997), Heckman, Heinrich, and Smith (1997), and Heckman, Smith, and Taber (1996).
} 
provides additional funds based only on total district enrollment. This change completely divorces special education funding from disability rates. Over the three years following the switch to this "census-based" regime, the number of students receiving special education declined by over 17 percent. Most of the students who were returned to general education had minor learning disabilities or speech impairments. Clearly, despite the state and federal regulations, there is room for districts to respond to both increased and decreased incentives.

While these case studies suggest that there is an important institutional take-up response, they are unable to quantify the relationship between changes in fiscal incentives and student disability rates. This paper attempts to estimate this elasticity, which will serve as a useful summary statistic for predicting district responses to specific school district reforms and for evaluating the role of fiscal incentives in determining the trend in student disability rates. I am also able to explore factors that affect how a district is likely to respond. The next section describes in more detail the methodology that will be used to measure the relationship between disability rates and fiscal incentives.

\section{Empirical Strategy}

In order to estimate the effect of the generosity of state special education reimbursements on student disability rates, I analyze the behavior of local school districts in Texas from 1991-92 to 1996-97. In Texas, as in many states, disabled students generate more state revenue than nondisabled students. The revenue gain to classifying an additional student is determined by a complicated school finance equalization scheme, which creates a non-linear schedule of incentives that depends on district wealth. Of particular interest is that this schedule was altered dramatically in the middle of the period due to a court-mandated change in the method of equalization. The local take-up response will be identified from the resulting sharp changes in the relative incentives faced by districts of low, middle, and high tax base wealth.

The empirical specification relates the logarithm of the fraction of the district student population classified as disabled (Disab) ${ }^{9}$ to the logarithm of the amount of additional state revenue raised by classifying an additional student as disabled (Gain):

\footnotetext{
${ }^{8}$ Montgomery (1995), p.18.

${ }^{9}$ I also estimated this relationship with the dependent variable expressed as the logarithm of the disability rate over one minus the disability rate. Modeling the disability rate as following an exponential distribution in this way explicitly accounts for the fact that the rate is bounded between zero and one. This model produces results that are
} 


$$
\begin{gathered}
\ln \left(\text { Disab }_{i t}\right)=\alpha_{i}+\alpha_{i} t+\beta \ln \left(\text { Gain }_{i t}\right)+\gamma_{1} \text { Middle Wealth }_{i t}+\gamma_{2} \text { HighWealth }_{i t} \\
+X_{i t} \Omega+\delta_{t}+\varepsilon_{i t}
\end{gathered}
$$

where $\mathrm{i}$ indicates district and $\mathrm{t}$ indicates year. Low, middle, and high are the tax base wealth categories that receive differential treatment under the school finance formula, and low wealth is the omitted category. These tax base wealth group indicators are included to control for any differences in the prevalence of disability or in district classification behavior across these groups that are not due to differences in fiscal incentives. The vector $\mathbf{X}$ includes community and student characteristics, such as the racial composition and poverty rate, that may affect either the underlying incidence of student disability or tastes for classifying mildly disabled students as disabled (Chaikind et al 1991, Harry 1992). The preferred specification also includes districtspecific trends in order to capture any time-varying omitted variables that affect disability rates and change smoothly over time. Thus, the effect of the fiscal gain will be determined by marked changes in the pattern of fiscal incentives that lead to deviations in the disability rate around the district trend. $\beta$ measures the elasticity of official student disability rates with respect to fiscal incentives.

In order to interpret $\beta$ as the causal effect of fiscal incentives on student disability rates, I need to isolate exogenous variation in the fiscal gain measure. Some of the components of the actual revenue gain a district receives depend on district choice variables that may in turn depend on the disability rate. For example, a district that aggressively reclassifies students will receive a flow of state funds that may allow the district to reduce the property tax rate, which in turn affects the incentive the district faces. ${ }^{10}$ Additionally, aggressive reclassification reduces measured per pupil wealth and may change the tax base wealth category into which a district falls. Therefore, as I describe in more detail below, I simulate both the revenue gain and the tax base wealth category for each district using only variables that are outside of the direct control of the district (at least in the short run). I use these simulated variables as instruments for the

\footnotetext{
very similar to the above model, and I therefore chose to present the estimates that are most readily interpretable.

${ }^{10}$ These feedback effects can be nontrivial. For example, a one standard deviation increase in the disability rate would generate enough additional state revenue to permit the median district to maintain the same level of spending while reducing its local tax rate by 7.8 percent. The reduction in the tax rate would in turn reduce the measured incentive for the median district by 5.5 percent. The moderate feedback effect for the median district masks very large effects for some districts: the district with largest resulting reduction in the incentive is predicted to witness a fall of 33 percent, and the district with the maximum increase is predicted to witness a 71 percent increase. These extreme changes are generated by districts that are predicted to switch tax base wealth category and incentive regime due to the change in district wealth per weighted pupil.
} 
potentially endogenous variables in equation (1). I will be estimating a system of equations of the form:

$$
\begin{aligned}
& \ln \left(\text { Gain }_{i t}\right)=\alpha_{1 i}+\alpha_{1 i} t+\beta_{1} \ln \left(\overline{\text { GAIN }}_{i t}\right)+\gamma_{11} \overline{\text { Middle }}_{i t}+\gamma_{12} \overline{\text { High }}_{i t}+\mathbf{X}_{i t} \Omega_{1}+\delta_{1 t}+\varepsilon_{1 i t} \\
& \text { Middle Wealth }{ }_{i t}=\alpha_{2 i}+\alpha_{2 i} t+\beta_{2} \ln \left(\overline{\text { GAIN }}_{i t}\right)+\gamma_{21} \overline{\text { Middle } i t}+\gamma_{22} \overline{\text { High }}_{i t}+\mathbf{X}_{i t} \Omega_{2}+\delta_{2 t}+\varepsilon_{2 i t} \\
& \text { HighWealth }_{i t}=\alpha_{3 i}+\alpha_{3 i} t+\beta_{3} \ln (\overline{G A I N} i t)+\gamma_{31} \overline{\text { Middleit }}+\gamma_{32} \overline{\text { High }}_{i t}+\mathbf{X}_{i t} \Omega_{3}+\delta_{3 t}+\varepsilon_{3 i t} \\
& D I S A B_{i t}=\alpha_{4 i}+\alpha_{4 i} t+\beta_{4} \ln \left(G_{A I N}\right)+\gamma_{41} \text { MiddleWealth }_{i t}+\gamma_{42} \text { HighWealth }_{i t}+\mathbf{X}_{i t} \Omega_{4}+\delta_{4 t}+\varepsilon_{4 i t} \text {, }
\end{aligned}
$$

where the bar indicates a simulated value. The instrumental variables estimate $\beta_{4}$ isolates the impact of variation in the revenue gain that is induced by changes in the state policy alone.

\section{Texas School Finance Policy}

I will review the structure of Texas school finance policy in order to clarify the nature of the variation in the revenue gain and the construction of the actual and simulated revenue gain and tax base wealth measures. Though the same basic formula was in place before and after the reform in 1993-94, the implementation changed dramatically. In Texas, districts that have less fiscal capacity (as measured by tax base wealth per pupil) and more student need (as measured by the pupil count) receive more aid. Classifying a student as disabled inflates the pupil count because a special education student is weighted to count as a multiple of a regular education student. There is an associated revenue gain because a higher pupil count increases measured need and reduces measured fiscal capacity, and both effects lead to higher state aid.

The magnitude of the revenue gain from reclassifying a student is determined by the coexisting foundation grant (Tier 1) and matching grant (Tier 2) programs. Tier 1 guarantees a certain amount of revenue per weighted pupil for levying the required tax rate $\left(r_{t}\right)$ :

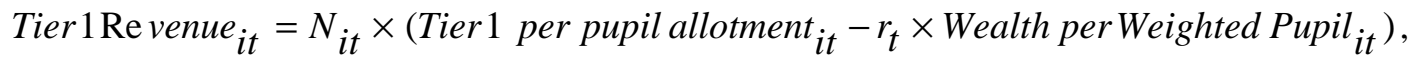
where $\mathrm{N}_{\mathrm{it}}$ is the weighted pupil count. Tier 2 guarantees a certain amount per pupil for each .01 percent tax, or mill, the district chooses to levy above the required Tier 1 rate: 


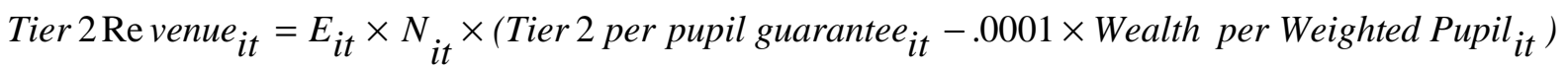

$$
E_{i t}=\operatorname{Min}\left(\left(t_{i t}-r_{t}\right) \times 10000, \operatorname{cap}_{t}\right) \text {, }
$$

where $E_{i t}$ is the number of mills matched by the state, $t_{i t}$ is the local tax rate, and cap th $_{t}$ the maximum number of mills matched. The term in parentheses is simply the gap between the per pupil guarantee per mill and the local revenue per pupil raised per mill.

The combined Tier 1 and 2 revenue gain from classifying a student as disabled can be found by calculating the change in both revenue amounts that would result from the associated increase in the weighted pupil count $\left(\partial \mathrm{N}_{\mathrm{it}}\right)$ :

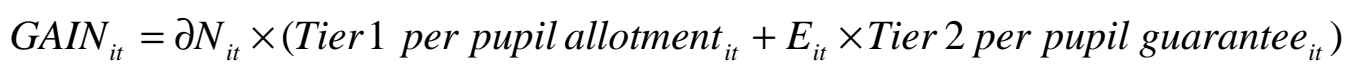

The gain depends on three factors: the increase in the pupil count (a) multiplied by the foundation program per pupil allotment (b) and by the amount of per pupil matching revenue (c). Of course, this formula only strictly holds if the revenue functions are continuous so that districts contribute revenue to the state if calculated Tier 1 or Tier 2 revenues are negative. If revenues are constrained to be non-negative under either program, then the relevant component (either $b$ or c) will be zero in the above gain formula for off-formula districts. In fact, challenges to the constitutionality of the equalization program led the legislature to switch from a system permitting only negative Tier 1 revenues to a system permitting only negative Tier 2 revenues in 1993-94. It is these changes in the non-linearity of the gain formula that provide the most important identifying variation in incentives to classify students as disabled.

\section{a) Marginal Increase in the Pupil Count $\left(\partial \mathrm{N}_{\mathrm{it}}\right)$}

The first term is a scaling variable that will enhance the variation that comes through the other two components of the fiscal gain. The amount that a disabled student adds to the pupil count over the amount a regular education student adds depends on the type of instruction that student receives. Each instructional setting, such as mainstream (additional support within the regular education classroom) or resource room (intensive instruction in a separate class for part of the school day), carries its own multiplier. To calculate the expected increase in the pupil count from classifying an additional student as disabled, I create a weighted average of the 
placement weights using the pattern of placement of disabled students. ${ }^{11}$ For the actual gain measure, this component is based on the pattern of placement within each district. Because a district's pattern of placement may reflect how aggressively the district classifies marginally disabled students as disabled, the simulated gain measure is based instead on the statewide fraction of disabled students served in each instructional setting.

The following table presents this simulated marginal increase in the pupil count by year:

\begin{tabular}{cccccc}
\hline \multicolumn{5}{c}{ Table A: Simulated Marginal Increase in the Pupil Count } \\
\hline $1991-92$ & $1992-93$ & $1993-94$ & $1994-95$ & $1995-96$ & $1996-97$ \\
.64 & .64 & .64 & .74 & .74 & .81 \\
\hline
\end{tabular}

On average over this period a disabled student counted as 1.71 students, for a marginal increase of .71 in the pupil count over the amount a regular education student contributes. In 1995-96, the legislature increased the weights on less restrictive placements in an attempt to encourage mainstreaming, leading to successive 16 percent and 10 percent increases in this scaling variable.

\section{b) Tier 1 per pupil allotment}

The level of the per pupil allotment under Tier 1 varies over time and by district. The nominal basic allotment was \$2200 in 1991-92, \$2400 in 1992-93, \$2300 in 1993-94 and 199495, and \$2387 in 1995-96 and 1996-97. The real value fell over time as the state faced difficulties in meeting all of it funding commitments under the school finance program.

The basic allotment is adjusted upward in two ways to account for differences in the cost of providing education across districts. The first is a price component that adjusts for exogenous variation in prices of educational inputs across districts. ${ }^{12}$ The second is an economies of scale component (which is rare in state aid formulas) that adjusts for presumed higher per-pupil costs in smaller and more sparsely populated districts. Because the scale adjustment is in part a

\footnotetext{
${ }^{11}$ For example, assume that half of disabled students are served in mainstream settings and half are served in resource room settings. In 1991-92, a student placed in a mainstream setting carries an excess weight of .25, and a student that spends an average amount of time in a resource room setting carries an excess weight of .9. The expected increment to the pupil count from classifying an additional student as disabled would be $.25 * .5+.9 * .5=.575$.

${ }^{12}$ The Legislative Education Board (LEB) and Legislative Budget Board (LBB) were required to develop this index in 1990. The price adjustment is based on the level of beginning teacher salaries in the counties contiguous to a district's county and is meant to capture regional variation in the labor market for teachers. See Ladd and Yinger (1994) for a discussion of methods of adjusting education finance formulas to account for cost differences across localities. Also, see Kenny and Denslow (1980) for an analysis of the factors underlying variation in teacher salaries across localities.
} 
function of the weighted pupil count and hence the student disability rate, the simulated gain will be based on the scale adjustment that would be predicted to apply given overall district enrollment. ${ }^{13}$ For the analysis, it is important that the financial gain be in real terms. I convert all values into 1991-92 dollars using growth in statewide average beginning teacher salaries as a deflator. ${ }^{14}$ I further adjust all financial variables for cross-district cost variation using the district-specific price indices. ${ }^{15}$

In the first two years of the sample period, a district that raised more than its total calculated Tier 1 allotment (Tier 1 per pupil allotment $\times \mathrm{N}_{\mathrm{it}}$ ) from the required levy faced the same incentives to classify students as disabled as any other district. Because the state collected the required local levy from each district and then redistributed the funds according to the each district's total Tier 1 allotment, any district could increase its claim on these redistributed resources by boosting its pupil count. However, this method of implicit resource transfer from higher to lower wealth districts was ruled unconstitutional, and starting in 1993-94 Tier 1 contributions can no longer exceed Tier 1 receipts. Under the current program, the local required contribution is not collected and is used only to calculate whether and how much Tier 1 aid a district receives. Therefore, marginal changes in the pupil count do not generate additional revenues for wealth districts that receive no aid. For these districts, component (b) becomes zero after 1992-93. The mean and standard deviation of component (b) used in the simulated gain measure are shown the following table:

\begin{tabular}{cccccc}
\hline \multicolumn{6}{c}{ Table B: Simulated Contribution from the Tier 1 Per Pupil Allotment } \\
\hline $1991-92$ & $1992-93$ & $1993-94$ & $1994-95$ & $1995-96$ & $1996-97$ \\
2816 & 3069 & 2669 & 2681 & 2802 & 2806 \\
$(380)$ & $(417)$ & $(892)$ & $(871)$ & $(880)$ & $(864)$ \\
\hline
\end{tabular}

The standard deviation increases after 1992-93 as the wealthiest districts no longer receive a revenue gain to reclassifying students through Tier 1.

\footnotetext{
${ }^{13}$ Excluding the district in question, I calculate the average ratio of the weighted pupil count to overall district enrollment within that district's enrollment decile in each year. I then inflate the district's enrollment by the ratio calculated from this jack-knife procedure, and use the resulting approximation of the weighted pupil count to predict which scale adjustment would apply.

${ }^{14}$ The results are not sensitive to deflating by the national consumer price index for services instead.

15 The Texas-developed district-specific price index had become outdated by the period of my analysis, and the legislature had refused to accept updates. Most of the variation ( 80 percent) in the price index can be explained by district enrollment and is absorbed by the control variables used in the analysis. None of the results that include
} 


\section{c) Tier 2 matching revenue $\left(\mathrm{E}_{\mathrm{it}} \times\right.$ Tier 2 per pupil guarantee $\left.\underline{i}_{\underline{i}}\right)$}

Tier 2 matching revenue depends on the tax rate that a district chooses to set and the per pupil state guarantee which is determined each year. ${ }^{16}$ Property-poor districts raise less than the guarantee per pupil (about \$22) for each .01 percent tax (i.e. tax base wealth is less than $\$ 220,000$ per weighted pupil) and receive a matching subsidy to meet the guarantee. In 1991-92 and 1992-93, districts that raised more than the guarantee per mill did not participate in this program. Starting in 1993-94, districts that raise more than the guarantee fall into two categories. Those that do not raise "too much" more continue not to be affected at all by this tier. However, the wealthiest districts (those that raise more than $\$ 28$ per pupil per mill, or have over $\$ 280,000$ in wealth per weighted pupil) have to return the excess to the state. This recapture transforms Tier 2 into a "matching tax" program for these high wealth districts. In effect, the implicit redistribution of local revenues that occurred through Tier 1 has shifted to Tier 2.

Just as the matching subsidy to low wealth districts increases with the weighted pupil count, the matching tax decreases for high wealth districts. Component (c) is as calculated by the formula for low wealth districts in all years and for high wealth districts in the second period, ${ }^{17}$ and equal to zero otherwise. In calculating the actual gain from classifying a student as disabled, I use the tax rate each district chooses to set (when the component is non-zero). However, this tax rate may be directly affected by the size of the disability program. Therefore, the simulated measure is based on the average tax rate by tax base wealth decile and year. ${ }^{18}$

The simulated contribution to the gain from the Tier 2 per pupil allotment is presented in the following table for the 1020 districts included in the analysis:

\footnotetext{
district-specific trends are affected if the nominal values are not adjusted by these district-specific indices.

16 The guarantee varies by district since it incorporates one-half of the cost and scale adjustments from Tier 1 . I abstract from this in the discussion but account for this when calculating the gain measures used in the analysis. In the simulated gain measure, I calculate the district-specific Tier 2 per-pupil guarantee using the predicted scale adjustment.

${ }^{17}$ In the formula, the Tier 2 per pupil guarantee is replaced by the $\$ 28$ limit on per mill revenues per weighted pupil for the high wealth districts that are subject to recapture. The gain from the reduced Tier 2 matching tax is also much higher for the high wealth group than the increased matching subsidy for the low wealth group because the entire local tax rate, including the Tier 1 required rate, is used to determine the amount of recaptured revenue $\left(\mathrm{E}_{\mathrm{it}}=\mathrm{t}_{\mathrm{it}}\right)$.

${ }^{18}$ I again use a jack-knife procedure, calculating the expected tax rate for each district based on the average in the district's wealth decile each year, excluding that district from the calculation.
} 


\begin{tabular}{lcccccc}
\hline \multicolumn{6}{c}{ Table C: Simulated Contribution from the Tier 2 Per Pupil Allotment } \\
\hline \multirow{2}{*}{ Low Wealth } & $1991-92$ & $1992-93$ & $1993-94$ & $1994-95$ & $1995-96$ & $1996-97$ \\
& 1017 & 1003 & 891 & 894 & 1156 & 1194 \\
& $(138)$ & $(142)$ & $(141)$ & $(138)$ & $(1561)$ & $(161)$ \\
Middle Wealth & 0 & 0 & 0 & 0 & 0 & 0 \\
& $(0)$ & $(0)$ & $(0)$ & $(0)$ & $(0)$ & $(0)$ \\
High Wealth & 0 & 0 & 5003 & 5073 & 5013 & 5116 \\
& $(0)$ & $(0)$ & $(771)$ & $(820)$ & $(812)$ & $(811)$ \\
\hline
\end{tabular}

Approximately 86 percent of districts fall into the low wealth, 5 percent into the middle wealth, and 9 percent into the high wealth category in any given year.

Combining the Tier 1 and Tier 2 programs yields actual and simulated measures by tax base wealth category and year. In addition to simulating components (a) and (c) as described, I take one more step to insure that the variation in the simulated revenue gain is not correlated with other factors that may separately affect disability rates. Whether a district falls into the low, middle, or high tax base wealth category depends on tax base wealth per weighted pupil. A district that aggressively expands programs other than general education may be able to move into a lower tax base wealth category by increasing the weighted pupil count, so that the actual revenue gain would reflect classifying behavior rather than vice versa. To avoid this type of endogeneity, I predict the tax base wealth group a district would be likely to be in, given overall enrollment and tax base wealth. ${ }^{19}$ This predicted tax base wealth category is used to determine the incentive regime that applies when calculating the simulated gain measure and also serves as an instrument for a district's actual category.

The mean of the simulated revenue gain by tax base wealth category and year is presented in Table 1. The average increase in revenues from classifying a marginal student as disabled over all years is $\$ 2703$. Without information on the marginal excess costs of educating students classified as disabled, it is difficult to tell whether or not this represents a net gain to districts. The best information available on the marginal costs of educating disabled students, from Chambers (1998), suggests that the most mildly disabled students cost on average at most 24 percent more to educate than regular education students. In comparison, the median revenue

\footnotetext{
${ }^{19}$ I use the same prediction for districts' weighted pupil counts described in footnote 13 to predict wealth per
} 
gain is 116 percent higher than median per pupil instructional expenditures for regular education students, suggesting that the majority of districts may in fact generate surplus revenue by classifying students within certain disability categories while still providing the typical set of services. $^{20}$ Figure 3 depicts the time pattern in the simulated measure, and highlights the 55 percent increase in the gain for high wealth districts that occurred in 1993-94. This increase occurred at the same time that middle and low wealth district incentives fell by eight percent. If school districts respond to fiscal incentives to classify students as disabled, the response should be reflected in the behavior of the wealthiest 10 percent of districts over time relative to that of other districts.

\section{Data and Exploratory Analysis}

The analysis is based on district-level data collected by the Texas Public Education Information Management System (PEIMS). PEIMS collects annual information on a wide range of student characteristics, including the number of students in each district by disability type and instructional setting. The data also include district tax rates, property wealth, and the other variables necessary to calculate state aid. I supplement this data with detailed community characteristics from the 1990 Census School District Data Book (SDDB).

There are between 1043 and 1050 districts each year, for a total potential sample of 6276 observations for the school years 1991-92 to 1996-97. I exclude the six special school districts that are not fiscally independent and for which the usually aid formulas do not apply. I also exclude districts that are missing the demographic data from the Census. These two restrictions reduce the sample by 1.1 percent. I also limit the sample to districts that always have non-zero disability rates ${ }^{21}$ and non-zero simulated and actual revenue gains, which allows both variables to be specified in logarithmic form in the analysis. This eliminates an additional 1.5 percent of the observations. The analysis is based on the remaining 1020 districts and 6114 observations, which represent 97.4 percent of the original sample.

Table 2 presents the summary statistics for the variables used in the analysis. The first column shows the mean and standard deviation for each variable for the full sample. Because

weighted pupil. Table $\mathrm{C}$ above is based on predicted tax base wealth categories.

${ }^{20}$ The gain is more likely to be a net gain when the additional contribution from the federal government per disabled student is considered. This amount was \$423 per child in 1993.

${ }^{21}$ The districts that ever have no students classified as disabled tend to be very small districts. Median enrollment 
most of the analysis is based on de-trended variables, the standard deviation removing districtspecific trends is shown below the overall standard deviation for those variables that change over time. The mean disability rate is 13.5 percent including all disabilities, and 12.5 percent including only non-physical disabilities. The disabilities that I classify as non-physical are the disabilities that are arguably most likely to be affected by fiscal incentives: learning disability, speech impairment, emotional disturbance, and other health impairments (which includes Attention Deficit Hyperactivity Disorder (ADHD)).

The next three columns in Table 2 display the summary statistics by simulated tax base wealth category, which determines the incentives a district faces. The percent of districts classified as low, middle, and high wealth is 86,5 , and 9 percent respectively. 97.5 percent of districts are assigned to the same category as the actual tax base wealth category, which is determined by dividing total tax base wealth by the actual weighted pupil count. The greatest discrepancy between simulated and actual tax base categories occurs for middle wealth districts due to the small range of qualifying per pupil wealth. There are some important differences in the demographic characteristics across the columns. The low wealth districts tend to have less well-educated adult populations, higher student poverty rates, and a higher fraction of students who are black. These differences suggest that low wealth districts have larger at-risk student populations, and can help to explain the higher incidence of student disability in these districts (Shiono and Berman 1995).

The summary statistics in Table 2 hide important time trends. Student enrollment in Texas increased each year of the sample period, rising 11 percent over the six years from 3.4 million to 3.8 million students. The number of students classified as disabled rose from 340,000 to 450,000 , or by 32 percent, leading to rising disability rates. Figure 1 shows that the rising rates are due mainly to increasing fractions of students classified within the non-physical disability categories; the fraction of students classified as learning disabled, speech impaired, emotionally disturbed, and other health impaired rose 34, 21, 31, and 158 percent respectively. However, it would be premature to attribute this growth to the rising fiscal incentives depicted in Figure 3 given that physical disability rates rose nearly as rapidly. The trend in both nonphysical and physical disability rates may be attributable to non-fiscal factors, such as worsening socio-demographic indicators (student poverty rates increased by 27 percent over the same 
period).

To provide an initial sense of the role of fiscal incentives in explaining the trend in disability rates, I compare differences in the growth in simulated revenue gains and growth in student disability rates across tax base wealth groups. Table 3 presents mean annual percent changes in these two variables for low, middle, and high wealth districts. I exclude the 10 percent of districts that switch tax base wealth categories in order to avoid introducing confounding changes in the composition of the three samples. In high wealth districts, the revenue gain from classification increased 16.3 percent annually, compared to an average increase of 5.2 and 4.7 percent in low and middle wealth districts, respectively. The relative growth in disability rates parallels the relative changes in fiscal incentives across groups. Disability rates in high wealth districts grew at nearly double the rate of low and middle wealth districts. Figure 4 also reveals a close relationship over time between changes in disability rates and fiscal incentives within and across wealth categories.

This initial evidence establishes that there is a strong correlation between patterns in special education enrollments and revenue gains. While the simple differences-in-differences strategy does not adequately control for other variables that are changing over time, it provides insight into the identification strategy implemented in the regression analysis.

\section{Empirical Analysis}

\section{Basic Results}

Table 4 presents instrumental variables estimates of the elasticity of student disability rates with respect to the revenue gain. The specification in each column is a variant of the system of equations (2) presented earlier in the text. The sample is based on the 6114 observations for non-special districts (with non-missing and non-zero observations) for the years 1991-92 to 1996-97. In addition to the revenue gain and tax base wealth category indicators, the first column includes size, location, and time variables in the control set. The variables included are indicators for which of the 20 regional service centers serves the district, a 10-part spline in the logarithm of district enrollment, ${ }^{22}$ the logarithm of the number of schools in the district, and year dummies. The specification in the second column adds detailed student and community

\footnotetext{
${ }^{22}$ The results do not depend on including these flexible controls for district size, and are very similar if only the natural logarithm of district enrollment is included in the control set.
} 
characteristics. In addition to the variables shown in the table, this specification also includes the 1990 variables from the School District Data Book from Table $1 .{ }^{23}$ The third column adds district fixed effects, and the fourth column adds district-specific trends.

The estimated elasticity is relatively constant across the four columns, ranging from .106 to .144 , and is statistically significant in all cases. The other variable that consistently has a strong positive impact on disability rates is the fraction of students that are economically disadvantaged. ${ }^{24}$ This link between disability and poverty has been well-documented elsewhere (e.g. Chaikind and Corman 1991). The fraction black is significantly positively related to the disability rate in the last two specifications that attempt to control for unobservable district characteristics. The fraction disabled decreases with district enrollment and with the fraction of students in the earlier grades. This last finding is consistent with the fact that one in 7.4 elementary education students is served in special education, while one in only 6.5 secondary education students is.

The bottom panel in Table 4 depicts the ordinary least squares estimates of the coefficient on the log of the revenue gain. The estimate is much smaller than the corresponding instrumental variables estimate in the fixed effect specification, and is actually negative and significant when district-specific trends are included. This reflects the potential for districts that aggressively classify students as disabled to shift to a reduced-incentive regime, so that the elasticity estimate based on the endogenous measure will be biased downward. The reduced incentive may come through several channels. For example, the district may move to a lower tax base wealth category, may place more students in the instructional settings for the mildly disabled that carry lower weights, or may reduce its tax rate. The OLS results emphasize the importance of using the simulated gain and tax base wealth categories to isolate variation in the revenue gain that arises from policy changes.

The preferred specification is based on the stringent identification strategy in column 4 that includes district-specific trends. The disability response is identified from deviations in the growth of disability rates around each district's trend that are caused by deviations around trend in the growth of incentives. The interpretation of estimated coefficient on the log of the revenue gain of .144 is that a ten percent increase in the revenue gain would lead to a 1.44 percent

\footnotetext{
${ }^{23}$ These variables include the age and educational attainment distributions of the adult population and the fraction of families with and no children.
} 
increase in the disability rate. From 1991-92 to 1996-97, disability rates grew annually by 3.6 percent on average in Texas. Actual revenue gains grew on average by nine percent annually. Thus, the elasticity estimate implies that fiscal incentives can explain over 35 percent of the time trend in disability rates over the six years. ${ }^{25}$ In comparison, the implied elasticity of student disability rates with respect to the rate of economic disadvantage ${ }^{26}$ suggests that worsening socioeconomic conditions can explain nearly half of the growth in student disability. While fiscal incentives have been very important in determining disability rates, other factors have played a more important role over this period.

The last two columns in Table 4 replicate the specification in column 4 using subsets of the overall disability rate as dependent variables. The actual and simulated revenue gains are calculated in both cases using instructional placement patterns for the disabilities represented. The dependent variable in column 5 is the rate of non-physical disability. The non-physical disability categories are those in which the majority of students classified have mild disabilities and are often not easily distinguishable from poor academic performers in regular education (Reschly 1996). The point estimate of the elasticity of non-physical disability rates with respect to fiscal incentives is larger than for all disabilities, as would be expected. A 10 percent increase in the fiscal gain is predicted to lead to a 1.67 percent increase in the rate of non-physical disability. Column 6 shows the regression results when the dependent variable is the rate of physical disability. Reassuringly, physical disability rates are found to be unresponsive to fiscal incentives. ${ }^{27}$ The rest of the analysis focuses on the more responsive non-physical disability categories.

Table 5 tests the robustness of the estimated elasticity of non-physical disability rates in a variety of ways. ${ }^{28}$ Each row of the table presents displays the estimated coefficient on the log of

\footnotetext{
${ }^{24}$ The rate of economic disadvantage is the fraction of students who are eligible for reduced-price or free lunch.

${ }^{25}$ There are two caveats to interpreting this as an estimate of the long-run impact of fiscal incentives. First, the measured response may reflect cross-district migration as well as reclassification, leading to an overestimate of the net impact on overall disability rates. However, migration is likely to respond more slowly than assessment practices. Second, the dependent variable is by necessity expressed as a stock variable rather than a flow variable so that the long-run impact on disability rates will be understated.

${ }^{26}$ Evaluating both variables at mean sample values yields an implied elasticity of student disability rates with respect to economic disadvantage of 0.57 . The rate of economic disadvantage grew on average by three percent each year.

${ }^{27}$ The sample in column 6 is restricted to the 80 percent of districts that always have non-zero physical disability rates, which excludes the smallest districts. The estimated elasticity for non-physical disability rates in this restricted sample remains positive and significant.

${ }^{28}$ A test that I conducted for which the results are not shown involves adding state aid per pupil to the set of control
} 
the revenue gain from a separate regression. Each specification is identical to column 5 in Table 4 , but is based on a different sample. The first row reproduces the estimate from Table 4. Rows 2-6 successively exclude observations that are based on changes between specific pairs of years from the analysis. The estimated elasticity is not significantly different from the base estimate and is statistically significantly different from zero in all but one case. The most notable difference in the results occurs when changes between 1992-93 and 1993-94 are excluded from the analysis. The point estimate falls to .034 and the standard error more than doubles to .103. It is straightforward to demonstrate the source of this loss of precision by calculating the amount of useful variation that remains in the log of the simulated revenue gain. ${ }^{29}$ When other years are excluded, the variation that remains in the simulated gain measure never falls below 96 percent of the base case. However, when the change between 1992-93 and 1993-94 is excluded, almost half of the variation in the simulated gain is lost. The striking relative movement in the simulated gain across tax base wealth categories between these two years is shown in Figure 3 . The results presented in rows 2-6 establish that it is primarily this policy change that identifies the disability rate response.

The remaining rows conduct additional sensitivity tests. Rows 7 and 8 demonstrate that the estimated elasticity does not appear driven by outliers in the dependent variable. In very small districts, small changes in the number disabled can generate large swings in the disability rate. Eliminating the smallest five percent of districts does not have a noticeable effect on the point estimate, nor does eliminating the largest five percent. Row 9 presents the coefficient estimate when the regression is based on the full sample and is weighted by the natural logarithm of district enrollment. Weighting the larger districts more heavily reduces the point estimate of the elasticity and the standard error slightly. Rows 10-12 present the estimated elasticity when the sample is divided into thirds according to district enrollment. The response is greatest for the smallest districts, still positive and significant but only a third as large for mid-size districts, and

\footnotetext{
variables. This variable accounts for possible income effects associated with changes in the school finance formula that may be correlated with the fiscal gain. I include actual state per pupil aid in the set of endogenous control variables and add predicted per pupil aid to the set of instruments. Per pupil aid is predicted using the same exogenous variables used to predict the revenue gain. Including this measure has almost no impact on the coefficient of interest, which is not surprising because the correlation between the two is nearly zero.

${ }^{29}$ I remove district-specific trends from all of the variables in the analysis. I then regress the de-trended log of the simulated gain measure on de-trended values of all of the other control variables. The standard deviation of the residual from this regression provides information on the amount of useful variation that remains in the simulated gain measure.
} 
positive but insignificant for the largest districts.

One possible explanation for the declining responsiveness by district size is that small districts are more able to respond to fiscal incentives because decision-making is more centralized. As district enrollment increases and is spread across more schools, the school-level incentive to classify students in response to fiscal incentives is weakened because the likelihood of receiving the full financial benefit is lower. To test whether the differential response may be due to differences in effective incentives, I split the sample into single-school and multipleschool districts. Among multiple-school districts, I further split the sample by district size and enrollment concentration. Enrollment concentration is measured by a Herfindahl index calculated for each district $\mathrm{i}: \mathrm{H}_{\mathrm{i}}=\Sigma_{\mathrm{si}}\left[\left(\mathrm{e}_{\mathrm{si}}\right) / \mathrm{e}_{\mathrm{i}}\right]^{2}$, where s identifies schools and e is enrollment. Consistent with the hypothesis, Table 6 shows that the measured elasticity is highest for singleschool districts, and is higher for more concentrated districts within each district size category among multiple-school districts.

Table 7 explores how the responsiveness varies by grade level. ${ }^{30}$ The representation of students within specific disability categories differs dramatically across grade levels. In both the elementary and secondary grades, over 90 percent of disabled students are classified as having disabilities that fall within the four categories I classify as non-physical disabilities: learning disability, speech impairment, emotional disturbance, and other health impairment. Within these, the dominant categories are learning disability and speech impairment. The mean disability rates presented in the first column in Table 7 demonstrate that these two categories are distributed very unevenly across elementary and secondary grades. While learning disability comprises 58 percent and speech impairment 34 percent of elementary student disability, learning disability comprises 87 percent and speech impairment only 3 percent of secondary student disability.

The second column in Table 7 presents the estimated elasticity of student disability rates with respect to the fiscal gain by grade level and disability category. The estimates are based on the familiar instrumental variables specification that includes district-specific trends and timevarying controls. The non-physical disability rate is responsive to fiscal gains at both elementary and secondary grade levels, though the point estimate is twice as large for the elementary grades.

\footnotetext{
${ }^{30}$ The sample for this analysis excludes the seven percent of districts that do not provide both elementary and secondary education in order to avoid confounding changes in sample composition across grade levels.
} 
While increases in the fraction classified as learning disabled drive the response found for secondary grades, increases in the fraction classified as speech impaired drive the response for elementary grades. This pattern of student classification in response to fiscal incentives is consistent with average age patterns found by Hanushek, Kain, and Rivkin (1998). Using individual-level panel data from Texas, they find that there is significant movement in and out of special education for children classified as speech impaired at earlier ages, and that the same holds true for learning disabled at later ages.

Together, the results in Tables 4-7 demonstrate that the qualitative finding that fiscal incentives play a significant role in determining disability rates is quite robust. Also, the relative magnitudes of the response across districts and grades conform to expectations. However, the finding that localities are sensitive to fiscal incentives when making decisions about student disability obviously has ambiguous welfare implications. The following extensions provide indirect evidence on the possible welfare effects of the take-up response by considering how student race/ethnicity and district fiscal constraints affect reclassification.

\section{Response by Student Race/Ethnicity}

The first extension explores how the response of student disability rates to fiscal incentives differs for minority students as compared to majority students. Independent of considerations of the impact of school finance policies, there has been extensive public debate and legal concern about the potential over-classification of minority students as disabled. ${ }^{31}$ It is true in general, and in Texas as well, that disability rates are higher among minorities (See Figure 5). However, several studies show that this "over-representation" can be explained to a large degree by differences in demographic characteristics that reflect real differences in the underlying prevalence of disability. ${ }^{32}$ In order to measure the impact of fiscal incentives, I do

\footnotetext{
31 These concerns date from Hobsen v. Hansen (Washington, D.C.) in 1967 under which the tracking system that used standardized tests as a basis for special education placement was determined to be unconstitutional since it discriminates against black and poor students. Concerns about minorities in special education persist: "The Federal Government has warned that New York City could lose Federal aid if it continues to shunt disproportionate numbers of black and Latino children into special education. [...] A two-year investigation by the United States Department of Education's office of civil rights found that African-American children in schools where the principals, faculty, and student body are mainly white are most likely to end up in special-education classes. [T]hese children are often dumped into special ed even when diagnostic tests reveal no need for it" (New York Times, December 2, 1998).

${ }^{32}$ Wagner (1995) finds a higher incidence among minorities of deafness, blindness, and other objective physical disabilities; Shiono et al (1995) calculate that blacks are twice as likely as whites to be born with low birth weight, which is an important factor determining the likelihood of childhood disability.
} 
not make any assumptions about whether the average rate of disability among minority groups relative to majority groups (controlling for observable characteristics) reflects true differences in the prevalence of disability or not. I simply observe whether or not districts that have incentives to expand special education populations draw disproportionately from minority groups relative to this baseline rate.

In order to test whether students in minority groups are more likely to be classified as disabled in response to fiscal incentives, I begin by examining the response of race/ethnicityspecific disability rates to fiscal incentives in the top panel in Table 8. In order to exclude observations for which the relevant disability rate is zero, the sample is restricted in each row to those districts in which student enrollment in the race/ethnicity category indicated comprises at least 2.5 percent of total enrollment. The first column reports the number of observations included in each sample. The second and third columns present the mean enrollment share and disability rate for white, Hispanic, and black students separately. The estimated elasticities of the race/ethnicity-specific disability rates with respect to fiscal incentives are reported in the fourth column. Each coefficient is from a separate regression based on the instrumental variables specification that includes district-specific trends, where the dependent variable in each case is the disability rate within the category indicated. While the standard errors are large so that none of the differences are statistically significant, black disability rates appear to be more responsive than either white or Hispanic disability rates.

To test more directly whether under-represented individuals within a community are more likely to be classified as disabled, I compare the responsiveness of disability rates across majority and non-majority students in the next two panels of Table 8 . The majority is defined to include students who fall within the dominant race/ethnicity category, and the non-majority includes all other students within the district regardless of whether or not they belong to traditional minorities. The three rows within each panel successively restrict the sample to districts in which the dominant category's share of enrollment is at least 50, at least 60, and at least 70 percent. When the dependent variable is the disability rate among majority students, the estimated elasticity is positive and significant except for in the sample in which the majority share is the greatest. Among districts in which there exists a group that comprises at least a simple majority, the estimated elasticity of non-majority student disability rates is twice as large as that for majority students. What is striking is that for non-majority students the magnitude of 
the effect of fiscal incentives increases steadily with the size of the majority. Moving from districts with a majority share of at least 50 percent to a majority share of at least 70 percent, the point estimate of the elasticity of the non-majority student disability rate with respect to the fiscal gain increases from .191 to .265.

The finding that non-majority students are more likely to be classified as disabled in response to fiscal incentives is consistent with two hypotheses with very different welfare implications. Districts could be "dumping" children of less politically powerful parents into special education to leverage state funds. Or, it may be that the implied reduction in the cost of serving special education students reduces barriers to minority children to securing the more intensive resources - though this seems unlikely given the concerns mentioned above. Despite the suggestive evidence that districts may be classifying non-majority students for fiscal gain, detailed information on the distribution of student ability by race/ethnicity would be needed to distinguish competing explanations.

\section{Response by District Fiscal Constraint}

The second extension tests whether or not students in districts that are fiscally constrained are more likely to be classified as disabled in response to increased incentives. Lacking a direct measure, I rely on changes in the level of net per pupil state aid received by districts to proxy for changes in fiscal constraint. The equalization reform that altered classification incentives also greatly affected the level of per pupil state aid flowing to districts. Though the fiscal incentive is highly nonlinear with respect to per pupil wealth, the net per pupil transfer from the state has a strong negative linear relationship with per pupil wealth. ${ }^{33}$ To identify whether changes in the net transfer affect the responsiveness to fiscal incentives, I add the level of per pupil aid and an interaction term between per pupil aid and the fiscal incentive to the regression. Per pupil aid is specified in levels because it is negative for many districts, so that the logarithm would be undefined. In order to ensure that the interaction term is not simply identifying differential behavior across districts of differing wealth, I add the level of per pupil district wealth to the control set (which already includes the logarithm of per pupil wealth). Per pupil aid is expressed in terms of standard deviations from the overall mean (as is the level of per

\footnotetext{
${ }^{33}$ The correlation between the simulated revenue gain and the level of per pupil wealth is 0.06 , while the correlation between the simulated per pupil transfer and the level of per pupil wealth is -0.95 .
} 
pupil district wealth) in order to simplify the interpretation of the coefficients. Because per pupil aid depends on endogenous district choice variables, the net per pupil transfer is simulated using only exogenous district characteristics in a fashion parallel to the calculation of the simulated incentive measure. The simulated measure then serves as an instrument for the actual level of per pupil aid.

Over the period, the median annual increase in the net per pupil transfer from the state is three percent a year. The net transfer fell by 15 percent and increased by 18 percent between years at the bottom and top deciles. Some districts are predicted to witness extreme changes in the level of net transfers, falling by over 100 percent or rising by more than 100 percent between years.

Table 9 reports the key coefficients from the expanded version of the usual instrumental variables specification with the fraction of students classified with non-physical disabilities as the dependent variable. The estimated main effect of per pupil aid is positive while the interaction term is negative, and both coefficients are significantly different from zero. Increases in the level of per pupil aid lead to higher fractions of students classified as disabled. Fixing the logarithm of the revenue gain at the mean of the sample, a one standard deviation in the level of the net per pupil transfer from the state (\$3851) would increase the fraction classified as disabled by five percent. The coefficient on the fiscal incentive is very similar to the base case, .162 with a standard error of .045 . This represents the elasticity at the average level of per pupil aid, since the average of the standardized aid measure is zero. However, the response varies directly with the level of net per pupil transfers. At the bottom tenth percentile of the level of net transfer, the implied elasticity of student disability rates with respect to fiscal incentives is .209. At the top tenth percentile, the implied elasticity is .108 . Greater responsiveness to fiscal incentives for reclassification when state aid per pupil is particularly low suggests that districts may assess students to be disabled to increase an otherwise weak claim on state resources.

While Hanushek, Kain, and Rivkin (1998) find that special education appears to improve students' performance on standardized exams, whether special education is equally beneficial for students classified in response to fiscal incentives remains an open question. The net benefit to these students will depend on whether or not the additional resources are directed toward them. Cullen and Figlio (1999) are able to conduct a more direct test than the above extensions by 
expanding the analysis to a nationally representative panel of districts. This broader approach makes it difficult to determine as explicitly which aspects of the school finance code identify the response of school districts to fiscal incentives, but allows matching to detailed special and regular education resource information available in the Schools and Staffing Survey. The measured quality of special education appears to decline in districts that face increasing fiscal incentives to reclassify students and are subject to binding tax limitations. This suggests that some districts may indeed reclassify students for fiscal gain while diverting the resources to other programs.

\section{Conclusion}

In this paper, I identify the response of official student disability rates to fiscal incentives by isolating sharp changes in the relative revenue gain from classifying students across school districts in Texas. The elasticity estimate suggests that a ten percent increase in the revenue generated by a special education student in excess of that generated by a regular education student leads to a 1.4 percent increase in the student disability rate. The response is greater for students classified with non-physical disabilities, as expected. Students are most likely to be classified as speech impaired in response to incentives in elementary grades, while learning disability populations are most sensitive in secondary grades. The estimate of the average elasticity implies that changes in state revenue generosity can explain over 35 percent of the trend in disability rates in Texas from 1991-92 to 1996-97. These findings demonstrate that bureaucratic take-up, much like individual take-up, is responsive to fiscal incentives.

The analysis also provides evidence that this form of local take-up is sensitive to district characteristics. Districts in which enrollment is more concentrated, and the effective incentive is likely to be stronger, are more responsive. Non-majority students are more likely to be classified as disabled in response to fiscal incentives, and more likely the greater is the size of the majority population. Also, districts are more likely to reclassify students in response to increases in fiscal incentives if the level of per pupil state aid is simultaneously low. Localities appear to manipulate special education populations to increase leverage on state funds, which may or may not be dedicated to special services for these students. A priority for future research is to resolve the ambiguous welfare implications of this take-up response. 


\section{Appendix: Texas Disability Eligibility Criteria}

\begin{tabular}{|c|c|}
\hline Disability (in order of prevalence) & Definition \\
\hline Learning Disability & $\begin{array}{l}\text { A disorder affecting a child's understanding of the use of spoken or written } \\
\text { language. The student's ability to listen, think, speak, read, write, spell, or do } \\
\text { mathematical calculations may be affected. }\end{array}$ \\
\hline Speech Impairment & $\begin{array}{l}\text { Determined by a certified speech and language therapist or pathologist to have } \\
\text { a disorder such as stuttering, impaired articulation, a language impairment, or a } \\
\text { voice impairment }\end{array}$ \\
\hline Emotional Disturbance & $\begin{array}{l}\text { Evaluated by a licensed psychologist or psychiatrist to have one or more of the } \\
\text { following: } \\
\text { a) inability to learn that cannot be explained by intellectual, sensory, or other } \\
\text { health factors } \\
\text { b) inability to build or maintain satisfactory interpersonal relationships } \\
\text { c) inappropriate types of behavior under normal circumstances } \\
\text { d) general pervasive mood of unhappiness or depression } \\
\text { e) tendency to develop physical symptoms or fears associated with personal or } \\
\text { school problems }\end{array}$ \\
\hline Mental Retardation & $\begin{array}{l}\text { Determined to be deficient in adaptive behavior and functioning two or more } \\
\text { standard deviations below the mean on individually administered scale of } \\
\text { verbal ability and nonverbal ability by a licensed psychologist of educational } \\
\text { diagnostician }\end{array}$ \\
\hline Other Health Impairment & $\begin{array}{l}\text { Determined by a licensed physician to lack strength, vitality, or alertness due to } \\
\text { chronic or acute problems }\end{array}$ \\
\hline Orthopedic Impairment & $\begin{array}{l}\text { Determined by a licensed physician to have a severe physical disability that } \\
\text { adversely affects educational performance (club foot, absence of a limb, } \\
\text { cerebral palsy, bone tuberculosis) }\end{array}$ \\
\hline Auditory Impairment & $\begin{array}{l}\text { Determined to have a serious hearing loss requiring corrective medical } \\
\text { treatment or use of amplification by an otological exam performed by an } \\
\text { otologist }\end{array}$ \\
\hline Visual Impairment & $\begin{array}{l}\text { a) determined by a licensed ophthalmologist of optometrist to have no vision or } \\
\text { serious visual loss after correction } \\
\text { b) determined to need special services based on a functional visual evaluation } \\
\text { by a certified professional }\end{array}$ \\
\hline Autism & $\begin{array}{l}\text { Determined by one individual from each of the following categories: } \\
\text { a) licensed physician, psychiatrist, or psychologist } \\
\text { b) certified speech and hearing therapist } \\
\text { c) educational diagnostician }\end{array}$ \\
\hline Deaf-blind & Has a combination of severe hearing and visual losses \\
\hline
\end{tabular}

Source: Texas Education Code, Special Education Provisions, 89.211 Eligibility Criteria. 


\section{References}

Anderson, Patricia M. and Bruce D. Meyer, 1997, "Unemployment Insurance Takeup Rates and the After-tax Value of Benefits," Quarterly Journal of Economics 112(3):913-37.

Bassi, Laurie J., 1988, "Poverty among Women and Children: What Accounts for the Change?," American Economic Review 78(2) May:91-95.

Bound, John and Timothy Waidmann, 1992, "Disability Transfers, Self-reported Health, and the Labor Force Attachment of Older Men: Evidence from the Historical Record," Quarterly Journal of Economics 107(4):1393-419.

Carter, Grace M., Joseph P. Newhouse, and David A. Relles, 1990, "How Much Change in the Case Mix Index is DRG Creep?," Journal of Health Economics 9(4):411-28.

Chaikind, Stephen and Hope Corman, 1991, "The Impact of Low Birthweight on Special Education Costs," Journal of Health Economics 10(3):291-311.

Chambers, Jay G., 1998, "The Patterns of Expenditures on Students with Disabilities: A Methodological and Empirical Analysis," in T. Parrish, J. Chambers, and C. Guarino, eds., Funding Special Education (Thousand Oaks, CA: Corwin Press, Inc.).

Chambers, Jay G., 1996, "Special Education Expenditures and Revenues in a Census-based Funding System: A Case Study of the Commonwealth of Massachusetts," Center for Special Education Finance State Analysis Series (Palo Alto, CA: American Institutes for Research).

Courty, Pascal and Gerald Marschke, 1997, "Measuring Government Performance: Lessons from a Federal Job-Training Program," American Economic Review 87(2):383-88.

Cullen, Julie Berry and David N. Figlio, 1998, "Local Gaming of State School Finance Policies: How Effective are Intergovernmental Incentives?," University of Michigan and University of Florida mimeo.

Hanushek, Eric A., John F. Kain, and Steven G. Rivkin,1998, "Does Special Education Raise Academic Achievement for Students with Disabilities?," National Bureau of Economic Research Working Paper No. 6691.

Harry, Beth, 1992, Cultural Diversity, Families and the Special Education System (New York, NY: Teacher's College Press).

Hartman, William T., 1980, "Policy Effects of Special Education Funding Formulas," Journal of Education Finance 6:135-59.

Heckman, James J., Carolyn Heinrich, and Jeffrey A. Smith, 1997, "Assessing the Performance of Performance Standards in Public Bureaucracies," American Economic Review 87(2):389-95.

Heckman, James J., Jeffrey A. Smith, and Christopher Taber, 1996, "What Do Bureaucrats Do? 
The Effects of Performance Standards and Bureaucratic Preferences on Acceptance into the JTPA Program," in Libecap, ed., Reinventing Government and the Problem of Bureaucracy (Greenwich, CT: JAI Press):191-217.

Kane, D. and P. Johnson, 1993, Vermont's Act 230: A New Response to Meeting the Demands of Diversity (Montpelier, VT: Vermont Department of Education).

Kenny, Lawrence W. and David A. Denslow, 1980, "Compensating Differentials in Teacher Salaries," Journal of Urban Economics 7:198-207.

Krueger, Alan B., 1990, "Incentive Effects of Workers' Compensation Insurance," Journal of Public Economics 41(1):73-99.

Kubik, Jeffrey D., 1997, "The Incentive Effects of Health-targeted Social Insurance," Massachusetts Institute of Technology Ph.D. dissertation.

Ladd, Helen F. and John Yinger, 1994, "The Case for Equalizing Aid," National Tax Journal 47(1):211-24.

Legislative Education Board State of Texas, 1991, Cost-of-Education Index 1992-93 Biennium: Final Report of the Legislative Education Board.

Lumsdaine, Robin L. and David A. Wise, 1994, "Aging and Labor Force Participation: A Review of Trends and Explanations," in Noguchi and Wise, eds., Aging in the United States and Japan: Economic Trends (Chicago, IL: University of Chicago Press), 7-41.

McLaughlin, M.J. and M.F. Owings, 1993, "Relationships Among States' Fiscal and Demographic Data and the Implementation of P.L. 94-142," Exceptional Children 59:247-261.

Mellard, Daryl F., 1985, "Report of the Learning Disability Field Study," submitted to Office of Education of the Exceptional Children of the Superintendent of Public Instruction, Frankfort, Kentucky.

Mellard, Daryl F., 1983, "Learning Disabilities Field Study: Final Report," Institute for Research in Learning Disabilities, University of Kansas.

Moffitt, Robert, 1992, "Incentive Effects of the U.S. Welfare System: A Review," Journal of Economic Literature 30(1):1-61.

Montgomery, Deborah L., 1995, "A Profile of Special Education Finance Reform in Oregon," Center for Special Education Finance State Analysis Series (Palo Alto, CA: American Institute for Research).

Moore, Mary T., E.W. Strang, M. Schwartz, and M. Braddock, 1988, Patterns in Special Education Service Delivery and Cost (Washington, D.C.: Decision Resources Group). 
Parrish, Thomas B., Fran O'Reilly, Ixtlac E. Duenas, and Jean Wolman, 1997, State Special Education Finance Systems, 1994-95 (Palo Alto, CA: American Institutes for Research).

Parrish, Thomas B., 1996, "Special Education Finance: Past, Present, and Future," Center for Special Education Finance Policy Paper No. 8 (Palo Alto, CA: American Institutes for Research).

Parsons, Donald O., 1980, “The Decline in Male Labor Force Participation," Journal of Political Economy 88(1):117-34.

Reschly, Daniel J., 1996, "Identification and Assessment of Students with Disabilities" in The Future of Our Children: Special Education for Students with Disabilities (Center for the Future of Children).

Reschovsky, Andrew, and Amy Ellen Schwartz, 1992, "Evaluating the Success of Need-Based State Aid in the Presence of Property Tax Limitations," Public Finance Quarterly 20:483-498.

Rothstein, Richard and Karen Hawley Miles, 1995, Where's the Money Gone? Changes in the Level and Composition of Education Spending (Washington, D.C.: Economic Policy Institute).

Shiono, Patricia H. and Richard E. Behrman, 1995, "Low Birth Weight: Analysis and Recommendations" in The Future of Our Children: Low Birth Weight (Center for the Future of Children).

Singer, Judith D., Judith S. Palfrey, John A. Butler, and Deborah Klein Walker, 1989, "Variation in Special Education Classification Across School Districts: How Does Where You Live Affect What You Are Labeled?," American Educational Research Journal 26:261-81.

Thurlow, M.L. and J.E. Ysseldyke, 1980, "Factors Influential on the Psychoeducational Decisions Reached by Educators," University of Minnesota Institute for Research in Learning Disabilities Research Report No. 25.

U.S. Department of Education, several years, Annual Report to Congress on the Implementation of the Individuals with Disabilities Act (Washington, D.C.: U.S. Government Printing Office).

U.S. General Accounting Office, 1994, "Rapid Rise in Children on SSI Disability Rolls Follows New Regulations," GAO/HEHS-94-225.

Verstegen, Deborah A., 1994, "Fiscal Provisions of the Individuals with Disabilities Education Act: Historical Overview," Center for Special Education Finance Policy Paper Number 2 (Palo Alto, CA: American Institutes for Research).

Wagner, M., 1995, "The Contributions of Poverty and Ethnic Background to the Participiation of Secondary School Students in Special Education," unpublished report to the Office of Special Education Programs, Department of Education. 
Ysseldyke, J., B. Algozzine, M. Shinne, and M. McGue, 1982, "Similarities and Differences Between Low Achievers and Students Classified as Learning Disabled," The Journal of Special Education 16:73-85.

</ref_section> 
Figure 1: Trend in Student Disability Rates in Texas

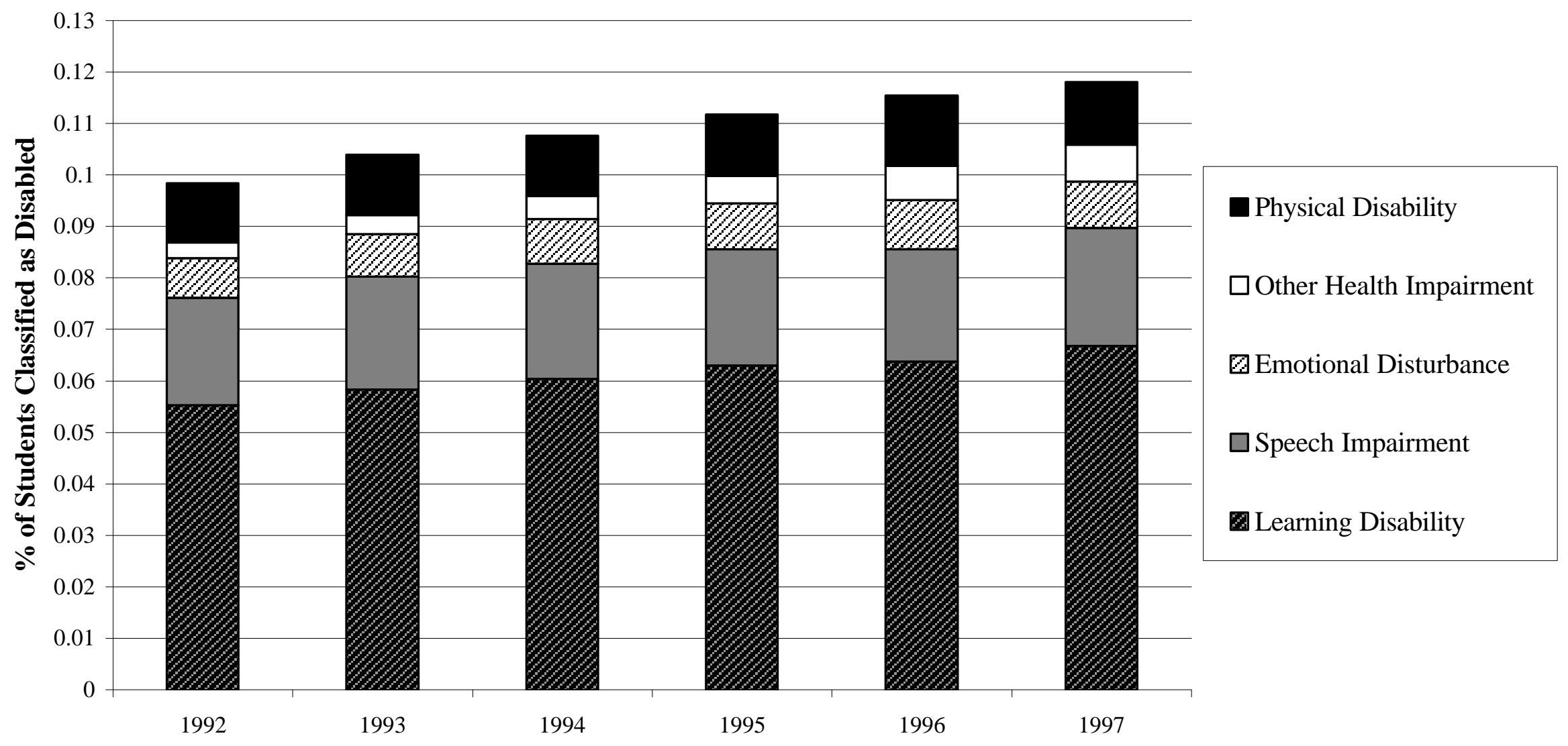

Notes to Figure 1: The height of the bar shows the fraction of elementary and secondary students in Texas that is classified as disabled in each year (Source: PEIMS). The bar is divided into the share attributed to each disability category: learning disability, speech impairment, emotional disturbance, other health impairment (which includes ADHD), and "physical" disability (which I define to include autism, deaf-blindness, hearing impairment, mental retardation, orthopedic impairment, traumatic brain injury, and visual impairment). 
Figure 2: Special Education Setting by Disability Type in Texas

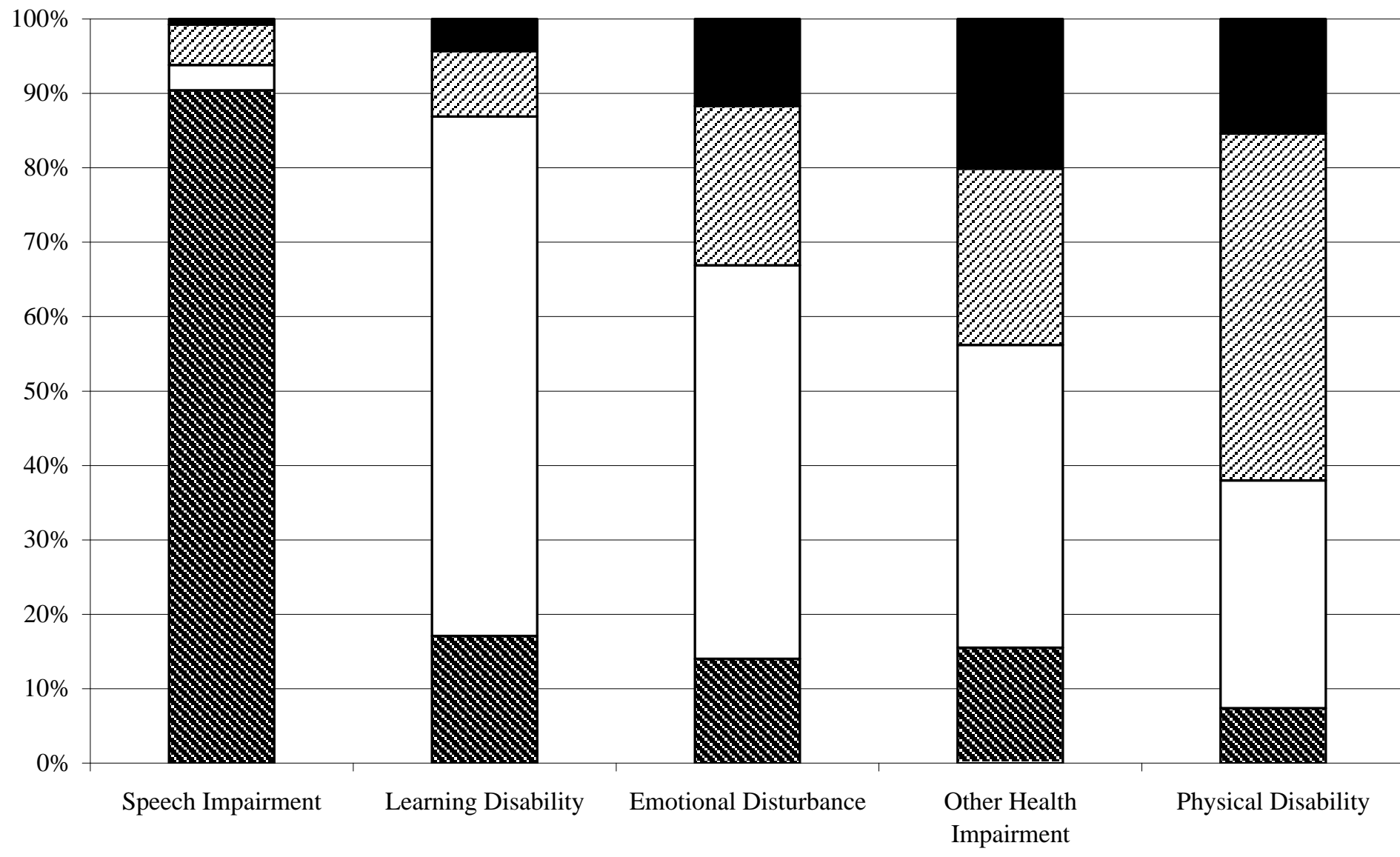

More Restrictive Setting

$\checkmark$ Self-Contained

Classroom

$\square$ Resource Room

Mainstream/Speech Pull-Out

Notes to Figure 2: The bars show the fraction of students wtihin each disability category that is served in the setting indicated. The placement patterns are based on data from Texas school districts for the years 1991-92 to 1996-97. More restrictive placements include separate schools. 


\section{Figure 3: Simulated Revenue Gain}

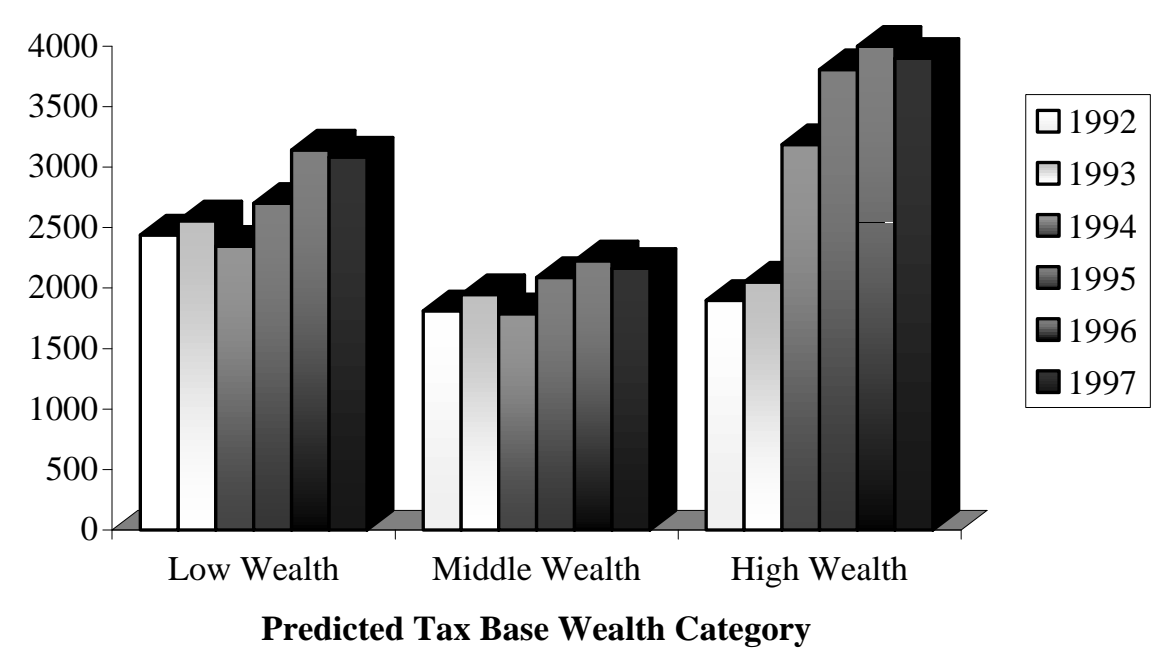

Table 1: Simulated Marginal Revenue Gain from Reclassifying a Student as Disabled

\begin{tabular}{|c|c|c|c|}
\hline \multirow[b]{2}{*}{ Year } & \multicolumn{3}{|c|}{ Predicted Tax Base Wealth Category } \\
\hline & $\underline{\text { Low Wealth }}$ & $\underline{\text { Middle Wealth }}$ & High Wealth \\
\hline 1991-92 & $\begin{array}{l}2440 \\
(354)\end{array}$ & $\begin{array}{l}1813 \\
(296)\end{array}$ & $\begin{array}{l}1898 \\
(312)\end{array}$ \\
\hline 1992-93 & $\begin{array}{l}2555 \\
(376)\end{array}$ & $\begin{array}{l}1948 \\
(312)\end{array}$ & $\begin{array}{l}2051 \\
(336)\end{array}$ \\
\hline 1993-94 & $\begin{array}{l}2346 \\
(348)\end{array}$ & $\begin{array}{l}1788 \\
(311)\end{array}$ & $\begin{array}{l}3186 \\
(718)\end{array}$ \\
\hline 1994-95 & $\begin{array}{l}2700 \\
(399)\end{array}$ & $\begin{array}{l}2089 \\
(360)\end{array}$ & $\begin{array}{l}3808 \\
(916)\end{array}$ \\
\hline 1995-96 & $\begin{array}{l}3143 \\
(460)\end{array}$ & $\begin{array}{l}2227 \\
(393)\end{array}$ & $\begin{array}{l}4000 \\
(968)\end{array}$ \\
\hline 1996-97 & $\begin{array}{c}3083 \\
(447)\end{array}$ & $\begin{array}{l}2164 \\
(370)\end{array}$ & $\begin{array}{l}3901 \\
(860)\end{array}$ \\
\hline
\end{tabular}

Notes to Figure 3 and Table 1: The values represent the increase in state revenue that would result if a locality were to classify a marginal regular education student as disabled. Means for each category and year are shown, standard deviations are in parentheses. The sample consists of all districts for the years 1991-92 through 1996-97 that have non-missing data and non-zero revenue gains and disability rates as described in the text (97.4\% of the full sample). Of the 6114 district-year observations, $86 \%$ are classified as low wealth, 5\% as middle wealth, and $9 \%$ as high wealth. The simulated revenue gain and tax base wealth categories are predicted using the state aid formula and exogenous district characteristics. 
Figure 4: Average Percent Change in Disability Rate and Revenue Gain
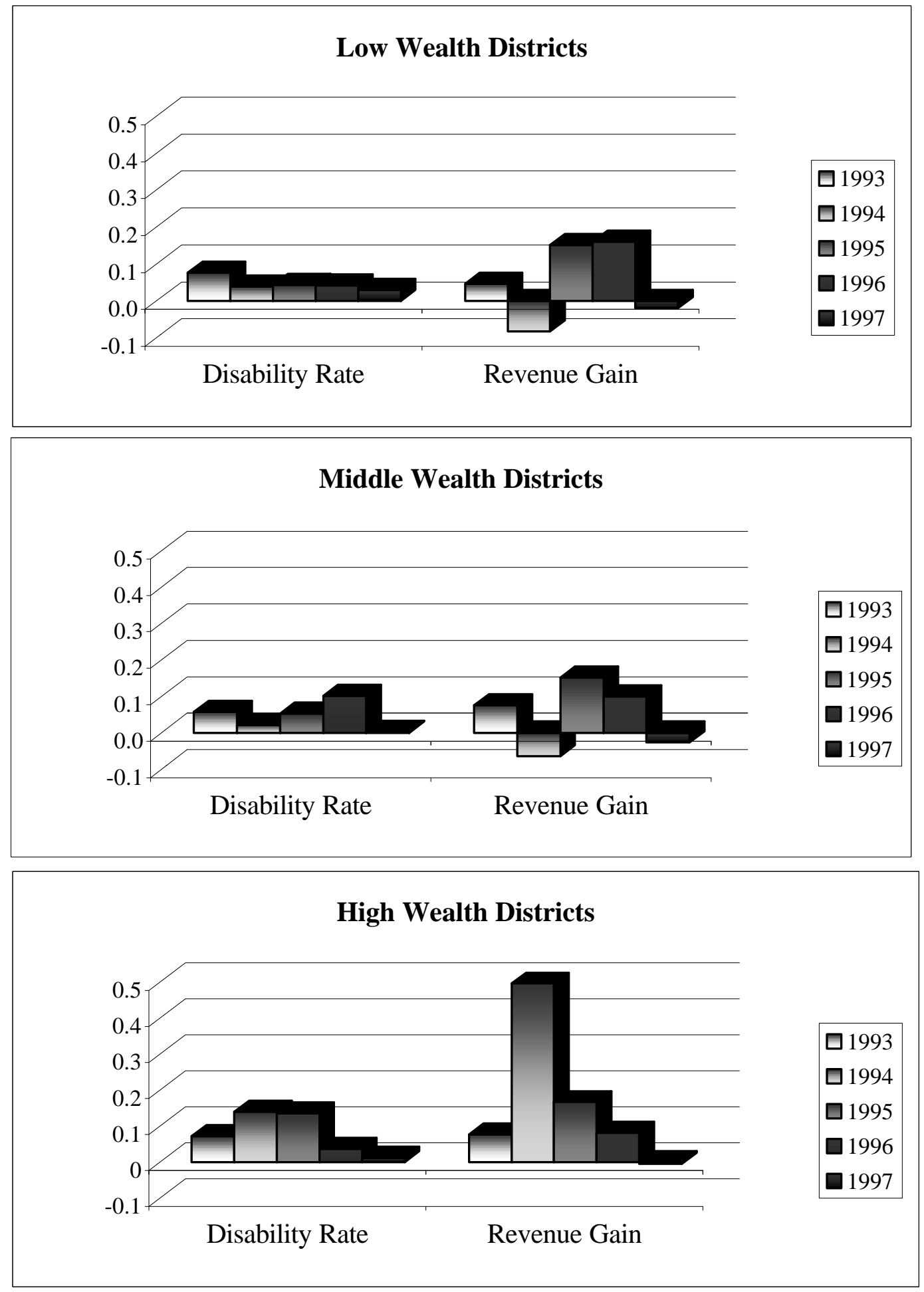

Notes to Figure 4: The sample in each panel is based on districts that are predicted to always fall within the given tax base wealth category ( 90 percent of the full sample). The height of the bars represents either the average percent change in the disability rate or the revenue gain between the indicated year and the prior year (e.g. "1997" represents the change between 
the school years 1995-96 and 1996-97). 
Figure 5: Fraction of Students Disabled by Race/Ethnicity in Texas

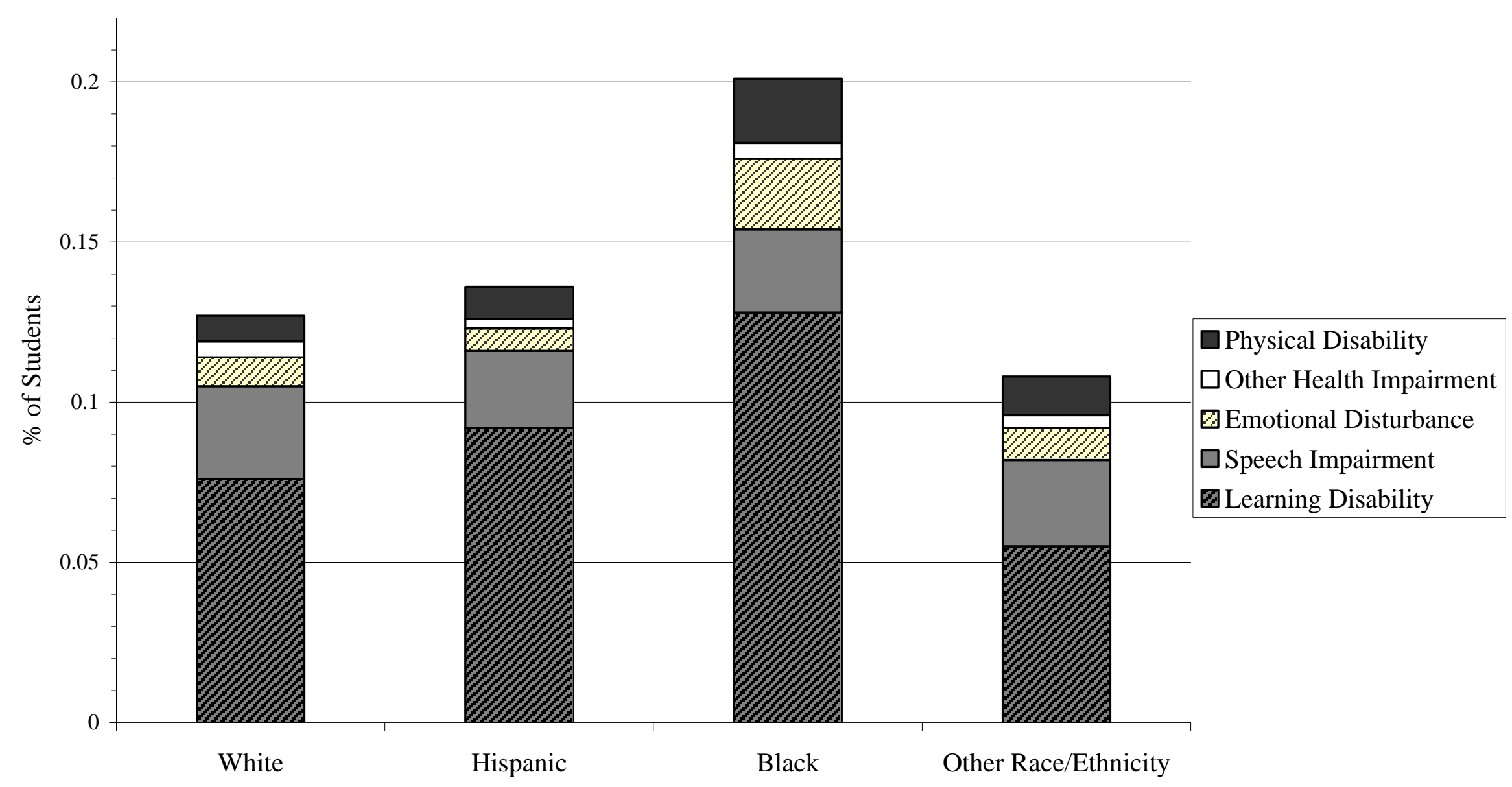

Notes to Figure 5: The height of the bar shows the average fraction of elementary and secondary students within each race/ethnicity category that is classified as disabled in Texas over the period 1991-92 to 1996-97. The bar is divided into the share attributed to each disability category, as in Figure 1. 
Table 2: Summary Statistics

\begin{tabular}{|c|c|c|c|c|}
\hline & Full Sample & Low Wealth & Middle Wealth & High Wealth \\
\hline \multicolumn{5}{|l|}{ District Characteristics } \\
\hline $\begin{array}{l}\text { Predicted Tax Base Wealth Group } \\
\% \text { Low Wealth } \\
\% \text { Middle Wealth } \\
\% \text { High Wealth }\end{array}$ & $\begin{array}{l}.860 \\
.048 \\
.092\end{array}$ & $\begin{array}{l}1 \\
0 \\
0\end{array}$ & $\begin{array}{l}0 \\
1 \\
0\end{array}$ & $\begin{array}{l}0 \\
0 \\
1\end{array}$ \\
\hline $\begin{array}{l}\text { Actual Tax Base Wealth Group } \\
\% \text { Low Wealth } \\
\% \text { Middle Wealth } \\
\% \text { High Wealth }\end{array}$ & $\begin{array}{l}.855 \\
.050 \\
.094\end{array}$ & $\begin{array}{l}.989 \\
.011 \\
.001\end{array}$ & $\begin{array}{l}.106 \\
.771 \\
.123\end{array}$ & $\begin{array}{c}0 \\
.046 \\
.954\end{array}$ \\
\hline Simulated Revenue Gain ${ }^{*}$ & $\begin{array}{l}2710 \\
(614) \\
{[389]}\end{array}$ & $\begin{array}{l}2714 \\
(503) \\
{[263]}\end{array}$ & $\begin{array}{l}2004 \\
(381) \\
{[798]}\end{array}$ & $\begin{array}{c}3043 \\
(1132) \\
{[772]}\end{array}$ \\
\hline Actual Revenue Gain* & $\begin{array}{l}2733 \\
(859) \\
{[586]}\end{array}$ & $\begin{array}{l}2766 \\
(798) \\
{[537]}\end{array}$ & $\begin{array}{l}2172 \\
(904) \\
{[879]}\end{array}$ & $\begin{array}{c}2713 \\
(1213) \\
{[803]}\end{array}$ \\
\hline Tax Base Wealth Per Pupil/1000* & $\begin{array}{c}212 \\
(359) \\
{[57]}\end{array}$ & $\begin{array}{l}128 \\
(60) \\
{[17]}\end{array}$ & $\begin{array}{l}327 \\
(77) \\
{[45]}\end{array}$ & $\begin{array}{l}934 \\
(875) \\
{[181]}\end{array}$ \\
\hline$\%$ of Tax Base Wealth Residential & $\begin{array}{l}.310 \\
(.187) \\
{[.020]}\end{array}$ & $\begin{array}{l}.333 \\
(.172) \\
{[.021]}\end{array}$ & $\begin{array}{l}.237 \\
(.217) \\
{[.015]}\end{array}$ & $\begin{array}{l}.135 \\
(.199) \\
{[.014]}\end{array}$ \\
\hline District Enrollment ${ }^{*}$ & $\begin{array}{c}3545 \\
(10808) \\
{[140]}\end{array}$ & $\begin{array}{c}3460 \\
(10036) \\
{[145]}\end{array}$ & $\begin{array}{c}7301 \\
(22409) \\
{[146]}\end{array}$ & $\begin{array}{c}2385 \\
(7660) \\
{[71]}\end{array}$ \\
\hline $\begin{array}{l}\text { \% Students in Early Education } \\
\text { (pre-K and kindergarten) }\end{array}$ & $\begin{array}{c}.096 \\
(.033) \\
{[.021]}\end{array}$ & $\begin{array}{c}.097 \\
(.032) \\
{[.019]}\end{array}$ & $\begin{array}{c}.093 \\
(.029) \\
{[.021]}\end{array}$ & $\begin{array}{c}.095 \\
(.044) \\
{[.033]}\end{array}$ \\
\hline$\%$ Students in Elementary Grades (1-6) & $\begin{array}{c}.476 \\
(.073) \\
{[.025]}\end{array}$ & $\begin{array}{c}.473 \\
(.063) \\
{[.024]}\end{array}$ & $\begin{array}{c}.495 \\
(.102) \\
{[.028]}\end{array}$ & $\begin{array}{c}.501 \\
(.119) \\
{[.035]}\end{array}$ \\
\hline$\%$ Students in Middle Grades (7-8) & $\begin{array}{l}.159 \\
(.031) \\
{[.020]}\end{array}$ & $\begin{array}{l}.160 \\
(.027) \\
{[.020]}\end{array}$ & $\begin{array}{l}.155 \\
(.041) \\
{[.025]}\end{array}$ & $\begin{array}{c}.152 \\
(.051) \\
{[.022]}\end{array}$ \\
\hline$\%$ Students in Secondary Grades $(9-12)$ & $\begin{array}{c}.264 \\
(.077) \\
{[.020]}\end{array}$ & $\begin{array}{c}.266 \\
(.071) \\
{[.018]}\end{array}$ & $\begin{array}{c}.253 \\
(.096) \\
{[.018]}\end{array}$ & $\begin{array}{c}.249 \\
(.110) \\
{[.030]}\end{array}$ \\
\hline Number of Schools ${ }^{*}$ & $\begin{array}{c}6.2 \\
(14.4) \\
{[0.5]}\end{array}$ & $\begin{array}{c}6.1 \\
(13.3) \\
{[0.5]}\end{array}$ & $\begin{array}{c}11.1 \\
(30.0) \\
{[0.6]}\end{array}$ & $\begin{array}{c}4.7 \\
(10.5) \\
{[0.5]}\end{array}$ \\
\hline \multicolumn{5}{|l|}{ Student Characteristics } \\
\hline Disability Rate $^{*}$ & $\begin{array}{l}.135 \\
(.044) \\
{[.018]}\end{array}$ & $\begin{array}{l}.136 \\
(.044) \\
{[.018]}\end{array}$ & $\begin{array}{l}.122 \\
(.038) \\
{[.017]}\end{array}$ & $\begin{array}{c}.126 \\
(.046) \\
{[.024]}\end{array}$ \\
\hline
\end{tabular}




\begin{tabular}{|c|c|c|c|c|}
\hline & Full Sample & Low Wealth & Middle Wealth & High Wealth \\
\hline Non-physical Disability Rate ${ }^{*}$ & $\begin{array}{l}.125 \\
(.044) \\
{[.018]}\end{array}$ & $\begin{array}{l}.126 \\
(.044) \\
{[.018]}\end{array}$ & $\begin{array}{c}.113 \\
(.038) \\
{[.017]}\end{array}$ & $\begin{array}{l}.119 \\
(.045) \\
{[.023]}\end{array}$ \\
\hline$\%$ Economically Disadvantaged & $\begin{array}{c}.448 \\
(.187) \\
{[.061]}\end{array}$ & $\begin{array}{c}.458 \\
(.186) \\
{[.060]}\end{array}$ & $\begin{array}{c}.390 \\
(.172) \\
{[.044]}\end{array}$ & $\begin{array}{c}.378 \\
(.178) \\
{[.073]}\end{array}$ \\
\hline$\%$ White & $\begin{array}{c}.656 \\
(.263) \\
{[.019]}\end{array}$ & $\begin{array}{c}.654 \\
(.268) \\
{[.018]}\end{array}$ & $\begin{array}{c}.660 \\
(.245) \\
{[.017]}\end{array}$ & $\begin{array}{c}.675 \\
(.226) \\
{[.024]}\end{array}$ \\
\hline$\%$ Black & $\begin{array}{c}.082 \\
(.122) \\
{[.009]}\end{array}$ & $\begin{array}{c}.086 \\
(.125) \\
{[.009]}\end{array}$ & $\begin{array}{c}.082 \\
(.125) \\
{[.005]}\end{array}$ & $\begin{array}{c}.044 \\
(.079) \\
{[.006]}\end{array}$ \\
\hline$\%$ Hispanic & $\begin{array}{c}.254 \\
(.266) \\
{[.017]}\end{array}$ & $\begin{array}{c}.253 \\
(.271) \\
{[.017]}\end{array}$ & $\begin{array}{c}.244 \\
(.239) \\
{[.015]}\end{array}$ & $\begin{array}{c}.270 \\
(.233) \\
{[.023]}\end{array}$ \\
\hline$\%$ Other Race/Ethnicity & $\begin{array}{l}.008 \\
(.017) \\
{[.004]}\end{array}$ & $\begin{array}{l}.007 \\
(.015) \\
{[.004]}\end{array}$ & $\begin{array}{c}.014 \\
(.026) \\
{[.005]}\end{array}$ & $\begin{array}{c}.012 \\
(.027) \\
{[.004]}\end{array}$ \\
\hline \multicolumn{5}{|l|}{ Community Characteristics } \\
\hline$\%$ Less Than High School Degree & $\begin{array}{c}.338 \\
(.110)\end{array}$ & $\begin{array}{c}.345 \\
(.108)\end{array}$ & $\begin{array}{c}.293 \\
(.108)\end{array}$ & $\begin{array}{c}.299 \\
(.115)\end{array}$ \\
\hline$\%$ High School Diploma & $\begin{array}{c}.312 \\
(.065)\end{array}$ & $\begin{array}{c}.313 \\
(.062)\end{array}$ & $\begin{array}{c}.298 \\
(.076)\end{array}$ & $\begin{array}{c}.309 \\
(.082)\end{array}$ \\
\hline$\%$ Attended Some College & $\begin{array}{c}.234 \\
(.070)\end{array}$ & $\begin{array}{c}.231 \\
(.070)\end{array}$ & $\begin{array}{c}.255 \\
(.072)\end{array}$ & $\begin{array}{c}.243 \\
(.069)\end{array}$ \\
\hline$\%$ Graduated College & $\begin{array}{l}.116 \\
(.067)\end{array}$ & $\begin{array}{l}.111 \\
(.056)\end{array}$ & $\begin{array}{c}.154 \\
(.096)\end{array}$ & $\begin{array}{l}.149 \\
(.112)\end{array}$ \\
\hline$\%$ 20-34 years & $\begin{array}{l}.206 \\
(.049)\end{array}$ & $\begin{array}{c}.206 \\
(.049)\end{array}$ & $\begin{array}{c}.207 \\
(.055)\end{array}$ & $\begin{array}{c}.208 \\
(.052)\end{array}$ \\
\hline$\%$ 35-49 years & $\begin{array}{l}.194 \\
(.036)\end{array}$ & $\begin{array}{l}.193 \\
(.033)\end{array}$ & $\begin{array}{l}.206 \\
(.042)\end{array}$ & $\begin{array}{c}.203 \\
(.048)\end{array}$ \\
\hline$\%$ 50-64 years & $\begin{array}{l}.143 \\
(.035)\end{array}$ & $\begin{array}{l}.143 \\
(.034)\end{array}$ & $\begin{array}{l}.144 \\
(.037)\end{array}$ & $\begin{array}{l}.141 \\
(.039)\end{array}$ \\
\hline$\% 65+$ years & $\begin{array}{l}.146 \\
(.062)\end{array}$ & $\begin{array}{l}.148 \\
(.062)\end{array}$ & $\begin{array}{l}.137 \\
(.063)\end{array}$ & $\begin{array}{c}.124 \\
(.063)\end{array}$ \\
\hline \% Families With No Children & $\begin{array}{c}.506 \\
(.085)\end{array}$ & $\begin{array}{c}.507 \\
(.085)\end{array}$ & $\begin{array}{c}.519 \\
(.080)\end{array}$ & $\begin{array}{c}.494 \\
(.084)\end{array}$ \\
\hline Number of Observations & 6114 & 5257 & 293 & 564 \\
\hline
\end{tabular}

Notes to Table 2: The first column presents summary statistics for the full sample of Texas non-special school districts (with non-missing and non-zero data as described in the text) for the years 1991-92 through 1996-97. The next three columns break the sample down by predicted tax base wealth group. Overall standard deviations are in parentheses, and standard deviations with district-specific trends removed are in brackets. The starred variables are specified in logarithmic form when included as control variables in empirical specifications. 
Table 3: Changes in District Revenue Gains and Student Disability Rates by Tax Base Wealth Category
Annual Percent Change in
Annual Percent Change in Simulated Revenue Gain
Disability Rate

\title{
Mean within Predicted Tax Base Wealth Category
}
Low Wealth [N=4992]
.052
.047
$(.001)$
Middle Wealth [N=54]
.047
.047
$(.012)$
(.019)
High Wealth [N=438]
.163
.080
$(.011)$
$(.017)$

\begin{abstract}
Notes to Table 3: The first column presents the mean annual percent change in the simulated revenue gain by predicted tax base wealth category for the years 1991-92 to 1996-97. The second column shows the annual percent change in the student disability rate. Standard errors are in parentheses. The sample is the subset of districts that are predicted not to switch tax base wealth category over the period (90\% of districts). This sample selection removes confounding changes in the composition of districts within tax base wealth groups.
\end{abstract}


Table 4: Instrumental Variables Estimates of the Relationship Between Fiscal Incentives and Student Disability Rates

\begin{tabular}{|c|c|c|c|c|c|c|}
\hline & $\begin{array}{c}\text { Year/ } \\
\text { Region/ } \\
\text { Size } \\
(1) \\
\end{array}$ & $\begin{array}{c}\text { Detailed } \\
\text { District } \\
\text { Chars. } \\
(2) \\
\end{array}$ & $\begin{array}{c}\text { District } \\
\text { Fixed } \\
\text { Effects } \\
(3) \\
\end{array}$ & $\begin{array}{c}\text { District- } \\
\text { Specific } \\
\text { Trends } \\
(4)\end{array}$ & $\begin{array}{c}\text { District- } \\
\text { Specific } \\
\text { Trends } \\
(5)\end{array}$ & $\begin{array}{c}\text { District- } \\
\text { Specific } \\
\text { Trends } \\
(6) \\
\end{array}$ \\
\hline & \multicolumn{6}{|c|}{ Dependent Variable: Ln(Student Disability Rate) } \\
\hline & \multicolumn{4}{|c|}{$\underline{\text { All Disabilities }}$} & $\begin{array}{l}\text { Non-physical } \\
\text { Disabilities }\end{array}$ & $\begin{array}{c}\text { Physical } \\
\text { Disabilities }\end{array}$ \\
\hline Ln(Revenue Gain) & $\begin{array}{l}.138 \\
(.039)\end{array}$ & $\begin{array}{l}.132 \\
(.046)\end{array}$ & $\begin{array}{l}.106 \\
(.026)\end{array}$ & $\begin{array}{l}.144 \\
(.040)\end{array}$ & $\begin{array}{l}.167 \\
(.040)\end{array}$ & $\begin{array}{l}-.112 \\
(.114)\end{array}$ \\
\hline Middle Wealth & - & $\begin{array}{l}.050 \\
(.028)\end{array}$ & $\begin{array}{l}.035 \\
(.029)\end{array}$ & $\begin{array}{l}.054 \\
(.044)\end{array}$ & $\begin{array}{l}.053 \\
(.046)\end{array}$ & $\begin{array}{l}-.007 \\
(.030)\end{array}$ \\
\hline High Wealth & - & $\begin{array}{l}.018 \\
(.021)\end{array}$ & $\begin{array}{l}-.057 \\
(.037)\end{array}$ & $\begin{array}{l}-.161 \\
(.065)\end{array}$ & $\begin{array}{l}-.202 \\
(.069)\end{array}$ & $\begin{array}{l}-.126 \\
(.049)\end{array}$ \\
\hline $\begin{array}{l}\text { Ln(Per Pupil Tax Base } \\
\text { Wealth) }\end{array}$ & - & $\begin{array}{l}-.012 \\
(.010)\end{array}$ & $\begin{array}{l}-.004 \\
(.022)\end{array}$ & $\begin{array}{l}.014 \\
(.029)\end{array}$ & $\begin{array}{l}.016 \\
(.031)\end{array}$ & $\begin{array}{l}.001 \\
(.024)\end{array}$ \\
\hline $\begin{array}{l}\% \text { Tax Base Wealth } \\
\text { Residential }\end{array}$ & - & $\begin{array}{l}.132 \\
(.034)\end{array}$ & $\begin{array}{l}-.002 \\
(.080)\end{array}$ & $\begin{array}{l}-.007 \\
(.106)\end{array}$ & $\begin{array}{l}.020 \\
(.113)\end{array}$ & $\begin{array}{l}.022 \\
(.090)\end{array}$ \\
\hline$\%$ Economically Disadv. & - & $\begin{array}{l}.337 \\
(.038)\end{array}$ & $\begin{array}{l}.219 \\
(.038)\end{array}$ & $\begin{array}{l}.171 \\
(.035)\end{array}$ & $\begin{array}{l}.200 \\
(.037)\end{array}$ & $\begin{array}{l}.239 \\
(.032)\end{array}$ \\
\hline$\%$ Hispanic & - & $\begin{array}{l}-.307 \\
(.038)\end{array}$ & $\begin{array}{l}.269 \\
(.101)\end{array}$ & $\begin{array}{l}-.029 \\
(.125)\end{array}$ & $\begin{array}{l}-.111 \\
(.132)\end{array}$ & $\begin{array}{l}.269 \\
(.152)\end{array}$ \\
\hline$\%$ Black & - & $\begin{array}{l}-.232 \\
(.043)\end{array}$ & $\begin{array}{l}.395 \\
(.169)\end{array}$ & $\begin{array}{l}.512 \\
(.246)\end{array}$ & $\begin{array}{l}.388 \\
(.262)\end{array}$ & $\begin{array}{l}.430 \\
(.238)\end{array}$ \\
\hline$\%$ Other Race/Ethnicity & - & $\begin{array}{l}-.248 \\
(.253)\end{array}$ & $\begin{array}{l}-.383 \\
(.526)\end{array}$ & $\begin{array}{l}-.096 \\
(.568)\end{array}$ & $\begin{array}{l}.134 \\
(.600)\end{array}$ & $\begin{array}{l}.713 \\
(.647)\end{array}$ \\
\hline$\%$ Early Ed. (pre-K and K) & - & $\begin{array}{l}-.504 \\
(.133)\end{array}$ & $\begin{array}{l}-.980 \\
(.115)\end{array}$ & $\begin{array}{l}-1.03 \\
(.135)\end{array}$ & $\begin{array}{l}-1.07 \\
(.144)\end{array}$ & $\begin{array}{l}-.717 \\
(.144)\end{array}$ \\
\hline$\%$ Elementary (grades 1-6) & - & $\begin{array}{l}-.404 \\
(.076)\end{array}$ & $\begin{array}{l}-.043 \\
(.096)\end{array}$ & $\begin{array}{l}-.379 \\
(.119)\end{array}$ & $\begin{array}{l}-.383 \\
(.126)\end{array}$ & $\begin{array}{l}-.090 \\
(.129)\end{array}$ \\
\hline$\%$ Middle (grades 7-8) & - & $\begin{array}{l}.002 \\
(.134)\end{array}$ & $\begin{array}{l}-.038 \\
(.124)\end{array}$ & $\begin{array}{l}-.209 \\
(.133)\end{array}$ & $\begin{array}{l}-.248 \\
(.141)\end{array}$ & $\begin{array}{l}-.147 \\
(.135)\end{array}$ \\
\hline Ln(Number of Schools) & $\begin{array}{l}.115 \\
(.013)\end{array}$ & $\begin{array}{l}.111 \\
(.013)\end{array}$ & $\begin{array}{l}.031 \\
(.016)\end{array}$ & $\begin{array}{l}-.019 \\
(.019)\end{array}$ & $\begin{array}{l}-.023 \\
(.020)\end{array}$ & $\begin{array}{l}-.007 \\
(.018)\end{array}$ \\
\hline $\begin{array}{l}\text { Includes } 20 \text { Region } \\
\text { Indicators }\end{array}$ & Yes & Yes & NA & NA & NA & NA \\
\hline $\begin{array}{l}\text { Includes } 1990 \text { Census } \\
\text { Variables }\end{array}$ & No & Yes & NA & NA & NA & NA \\
\hline \multirow[t]{2}{*}{$\begin{array}{l}\text { Includes Ln(Enrollment) } \\
\text { Spline and Year Indicators }\end{array}$} & Yes & Yes & Yes & Yes & Yes & Yes \\
\hline & \multicolumn{6}{|c|}{ Ordinary Least Squares Estimates } \\
\hline Ln(Revenue Gain) & $\begin{array}{c}.225 \\
(.014)\end{array}$ & $\begin{array}{c}.193 \\
(.015)\end{array}$ & $\begin{array}{c}.025 \\
(.010)\end{array}$ & $\begin{array}{l}-.022 \\
(.012)\end{array}$ & $\begin{array}{l}-.015 \\
(.012)\end{array}$ & $\begin{array}{l}.075 \\
(.018)\end{array}$ \\
\hline
\end{tabular}


Notes to Table 4: The dependent variable in columns 1-4 is the natural logarithm of the student disability rate in the district and year. Columns 1-4 progressively add more comprehensive control variables-only selected coefficients are presented in the table. Column 1 includes indicators for year and region (there are 20 regional educational service areas), a 10-part spline in the logarithm of district enrollment, and the logarithm of the number of schools. Column 2 adds the detailed district and community characteristics shown in Table 1, including the 1990 Census community variables from the School District Data Book. Column 3 includes district fixed effects, and column 4 includes district-specific trends. The dependent variable in column 5 is the non-physical disability rate, which is defined as the fraction of students with either learning disabilities, speech impairments, other health impairments (which includes ADHD), or emotional disturbances. In this case, the sample is restricted to the 80 percent of districts that always have non-zero physical disability rates. The dependent variable in column 5 is the physical disability rate. In the top panel, the actual revenue gain and tax base wealth categories are treated as endogenous. The instruments for these variables are simulated measures based only on the structure of the state school finance policy in each year and factors outside district control. The bottom panel presents the coefficient on the actual revenue gain from OLS specifications (which include actual tax base wealth categories as well) for comparison. The sample is based on all non-special districts (with non-missing and non-zero observations as described in the text) for the years 1991-92 to 1996-97. The total number of observations is 6114. 
Table 5: Sensitivity Analysis

\begin{tabular}{|c|c|c|}
\hline Row & Specification & $\begin{array}{l}\text { Estimated Coefficient on } \\
\text { Ln(Revenue Gain) }\end{array}$ \\
\hline \multirow[t]{2}{*}{ (1) } & Base Specification (Column 5 from Table 4) & $\begin{array}{l}.167 \\
(.040)\end{array}$ \\
\hline & Excluding Changes Between Pairs of Years: & \\
\hline (2) & $1991-92$ to $1992-93$ & $\begin{array}{l}.114 \\
(.037)\end{array}$ \\
\hline (3) & $1992-93$ to $1993-94$ & $\begin{array}{c}.034 \\
(.103)\end{array}$ \\
\hline (4) & $1993-94$ to $1994-95$ & $\begin{array}{c}.209 \\
(.041)\end{array}$ \\
\hline (5) & $1994-95$ to $1995-96$ & $\begin{array}{c}.214 \\
(.046)\end{array}$ \\
\hline (6) & $1995-96$ to $1996-97$ & $\begin{array}{l}.164 \\
(.043)\end{array}$ \\
\hline (7) & Excluding Smallest 5\% of Districts & $\begin{array}{l}.169 \\
(.037)\end{array}$ \\
\hline (8) & Excluding Largest $5 \%$ of Districts & $\begin{array}{l}.167 \\
(.042)\end{array}$ \\
\hline (9) & Weighting by Ln(District Enrollment) & $\begin{array}{c}.144 \\
(.036)\end{array}$ \\
\hline (10) & By Enrollment Size Thirds: Smallest Third & $\begin{array}{c}.323 \\
(.103)\end{array}$ \\
\hline (11) & Middle Third & $\begin{array}{l}.140 \\
(.072)\end{array}$ \\
\hline (12) & Largest Third & $\begin{array}{c}.046 \\
(.035)\end{array}$ \\
\hline
\end{tabular}

Notes to Table 5: Each row corresponds to a separate instrumental variables regression. All specifications include district-specific trends and control variables as in column 5 in Table 4 . The dependent variable is the natural logarithm of the fraction of students classified as having non-physical disabilities. The coefficients on the logarithm of the revenue gain and the associated standard errors are presented. The sample is based the 6114 district-year observations for all non-special districts (with non-missing and non-zero observations as described in the text) for the years $1991-92$ to $1996-97$. 
Table 6: Classification Response by District Size and Enrollment Concentration

\begin{tabular}{|c|c|c|c|}
\hline & $\begin{array}{l}\text { Median Enrollment } \\
\text { Concentration Index }\end{array}$ & $\begin{array}{l}\text { Coeff } \\
\text { Ln(Reve }\end{array}$ & $\begin{array}{l}\text { ent on } \\
\text { ue Gain) }\end{array}$ \\
\hline $\begin{array}{l}\text { Single-school districts } \\
\qquad[\mathrm{N}=1212]\end{array}$ & 1.00 & & \\
\hline Multiple-school districts & & $\begin{array}{c}\text { Below Median } \\
\text { Concentration Level }\end{array}$ & $\begin{array}{c}\text { Above Median } \\
\text { Concentration Level }\end{array}$ \\
\hline $\begin{array}{l}\text { Smallest Third } \\
\qquad[\mathrm{N}=810,810]\end{array}$ & .502 & $\begin{array}{l}.031 \\
(.092)\end{array}$ & $\begin{array}{l}.211 \\
(.116)\end{array}$ \\
\hline $\begin{array}{l}\text { Middle Third } \\
\qquad[\mathrm{N}=834,834]\end{array}$ & .344 & $\begin{array}{l}-.021 \\
(.061)\end{array}$ & $\begin{array}{l}.345 \\
(.130)\end{array}$ \\
\hline $\begin{array}{l}\text { Largest Third } \\
\qquad[\mathrm{N}=804,810]\end{array}$ & .158 & $\begin{array}{l}.047 \\
(.054)\end{array}$ & $\begin{array}{l}.125 \\
(.078)\end{array}$ \\
\hline
\end{tabular}

Notes to Table 6: The first column presents the median district enrollment concentration index by district type and size, where the index is equal to the sum of the squared share of district enrollment across schools within districts. The sample in the first row includes only single-school districts. The next rows divide the sample of multiple-school districts according to district size. The coefficients on the logarithm of the revenue gain (and associated standard errors) are shown from separate instrumental variables regressions for the samples indicated. The dependent variable in each case is the natural logarithm of the fraction of students classified as having non-physical disabilities. All specifications include district-specific trends and control variables as in column 5 in Table 4 . The sub-samples are based on the full sample of 6114 district-year observations for all non-special districts (with non-missing and non-zero observations as described in the text) for the years 1991-92 to 1996-97. 
Table 7: Classification Response by Disability Type and by Grade Level

\begin{tabular}{lcc}
\hline Dependent Variable & $\begin{array}{c}\text { Mean of the Dependent } \\
\text { Variable expressed in Levels }\end{array}$ & $\begin{array}{c}\text { Estimated Coefficient on } \\
\text { Log(Revenue Gain) }\end{array}$ \\
\hline Non-physical Disability Rate & \multicolumn{1}{c}{ Elementary Grades (Ages 6-11) } \\
Learning Disability Rate & $(.041)$ & .169 \\
& .067 & $(.058)$ \\
Speech Impairment Rate & $(.031)$ & -.028 \\
& .039 & $.079)$ \\
& $(.021)$ & $(.100)$ \\
\hline
\end{tabular}

Secondary Grades (Ages 12+)

$\begin{array}{lcc}\text { Non-physical Disability Rate } & .141 & .086 \\ & (.057) & (.041) \\ \text { Learning Disability Rate } & .122 & .125 \\ & (.050) & (.048) \\ \text { Speech Impairment Rate } & .004 & -\end{array}$

\footnotetext{
Notes to Table 7: The first column presents the mean and standard deviation of the specified disability rates within elementary and secondary grades. The second column presents the coefficient on the log of the revenue gain (and associated standard error) from specifications that include district-specific trends and control variables as in column 5 in Table 4. The dependent variable is the natural logarithm of the relevant disability rate. The sample in each row is derived from the full sample of 6114 district-year observations, but excludes school districts that provide either only elementary or secondary education (6.7\% of the full sample). Districts are also excluded in cases where the district ever classified no students within the specified disability category. This potential sample selection is minor, with at most 2 percent of observations excluded. The specification with the speech impairment rate in secondary grades as the dependent variable was not estimated because nearly 75 percent of districts have a zero rate of speech impairment for students in that age range.
} 
Table 8: Classification Response by Student Race/Ethnicity

\begin{tabular}{lcccc}
\hline Race/Ethnicity & $\begin{array}{c}\text { Number } \\
\text { of Obs. }\end{array}$ & $\begin{array}{c}\text { Enrollment } \\
\text { Share }\end{array}$ & $\begin{array}{c}\text { Non-physical } \\
\text { Disability Rate }\end{array}$ & $\begin{array}{c}\text { Coefficient on } \\
\text { Ln(Revenue Gain) }\end{array}$ \\
\hline \multirow{2}{*}{ White } & $(1)$ & $(2)$ & $(3)$ & $(4)$ \\
\multirow{2}{*}{ Hispanic } & 5869 & .680 & .119 & .127 \\
& & $(.003)$ & $(.001)$ & $(.049)$ \\
Black & 4686 & .319 & .130 & .112 \\
& & $(.004)$ & $(.001)$ & $(.077)$ \\
& 2838 & .166 & .174 & .218 \\
& & $(.003)$ & $(.002)$ & $(.091)$ \\
\hline
\end{tabular}

Non-majority

\begin{tabular}{lcccc} 
Majority Share $>.5$ & 4938 & .752 & .121 & .109 \\
& & $(.002)$ & $(.001)$ & $(.048)$ \\
Majority Share $>.6$ & \multirow{2}{*}{4074} & .795 & .122 & .124 \\
& & $(.002)$ & $(.001)$ & $(.051)$ \\
Majority Share $>.7$ & \multirow{2}{*}{3168} & .839 & .123 & .063 \\
& & $(.001)$ & $(.001)$ & $(.067)$
\end{tabular}

Non-majority

\begin{tabular}{ccccc} 
Majority Share .5 & 4938 & .248 & .147 & .191 \\
& & $(.002)$ & $(.001)$ & $(.079)$ \\
Majority Share .6 & \multirow{2}{*}{4074} & .205 & .150 & .231 \\
& & $(.002)$ & $(.001)$ & $(.089)$ \\
Majority Share $>7$ & \multirow{2}{*}{3168} & .161 & .153 & .265 \\
& & $(.001)$ & $(.001)$ & $(.127)$
\end{tabular}

Notes to Table 8: Each row provides statistics for the race/ethnicity category indicated. The sample in each case is restricted to districts in which the specific race/ethnicity category comprises at least 2.5 percent of total enrollment. This restriction reduces potential sample selection due to zero disability rates. Majority refers to the race/ethnicity category that comprises at least 50 percent of total enrollment within a district, while non-majority refers to all students who are not within the majority race/ethnicity category. The sample includes only districts in which the majority share of enrollment is at least 50 percent, at least 60 percent, and at least 70 percent when indicated. Columns 2 and 3 present the mean share of district enrollment and mean disability rate. The third column presents the coefficient on the logarithm of the revenue gain from separate instrumental variables regressions. In each case, the dependent variable is the natural logarithm of the share of disabled students within the indicated category. All specifications include district-specific trends and control variables as in column 5 in Table 4. Standard errors are in parentheses in all cases. 
Table 9: Classification Response by Net Per Pupil Transfer from the State

\begin{tabular}{lc} 
Independent Variable & $\begin{array}{c}\text { Coefficient } \\
\text { (Standard Error) }\end{array}$ \\
\hline Ln(Revenue Gain) & .162 \\
Net Per Pupil Transfer from State & $.045)$ \\
Ln(Revenue Gain) $*$ Net Per Pupil Transfer & .840 \\
\cline { 2 - 2 } Implied elasticity at $10^{\text {th }}$ percentile of net transfer & $(.230)$ \\
Implied elasticity at $90^{\text {th }}$ percentile of net transfer & -.101 \\
& $(.028)$ \\
\hline
\end{tabular}

Notes to Table 9: The estimates are based on a single instrumental variables specification that includes districtspecific trends and time-varying controls as in column 5 in Table 4 (with the addition of the level of per pupil wealth due to the strong linear relationship between this variable and net per pupil transfers). The dependent variable is the logarithm of the fraction of students with non-physical disabilities. The estimated coefficient on the logarithm of the revenue gain is presented in the first column, on the net per pupil transfer in the second, and on the interaction between the two in the third. Net per pupil transfers have been standardized to have mean zero and a standard deviation of one for this analysis. Actual transfers are endogenous to district decision-making, so predicted net per pupil transfers (also standardized) are included in the instrument set. The number of observations is 6114 . 